\title{
The Tobacco Agreement That Went Up in Smoke: Defining the Limits of Congressional Intervention into Ongoing Mass Tort Litigation
}

\author{
Maria Gabriela Bianchini $\uparrow$
}

Mass tort litigation is a topic discussed often in legal scholarship. Although Congress could provide an alternative forum to the courts in which to remedy mass tort injuries, Congress has not passed comprehensive mass tort reform legislation, and the legal literature has not examined implications that might stem from legislative reform.

Recently, major tobacco companies and the attorneys general of forty states asked Congress to enact a legislative version of the Proposed Tobacco Industry Settlement, a document the state attorneys general and the tobacco companies had originally negotiated in the course of litigation. In considering whether to enact the Proposed Settlement, Congress became directly involved in resolving a mass tort suit. Recognizing that the litigants who drafted the Proposed Settlement essentially sought to substitute a legislative remedy for a judicial remedy in resolving the suit, this Comment uses the document to discuss differences between legislative and judicial treatment of mass tort cases and the possible implications of substituting the political process for the judicial process. It asks what limits, if any, Congress should recognize on the political process when it intervenes into ongoing mass tort litigation.

\section{INTRODUCTION}

On June 25, 1997, the Supreme Court announced its opinion in Amchem Products, Inc. v. Windsor, ${ }^{1}$ where it rejected the latest in a long

Copyright $\odot 1999$ California Law Review, Inc.

$\dagger$ Staff Attorney, Division of Corporation Finance, United States Securities and Exchange Commission. J.D., School of Law, University of California, Berkeley (Boalt Hall), 1998; B.A., Williams College, 1994. A number of people dedicated time and effort to this Comment. Ellen LaPointe, Gillian Brown, Janine Leigh Kramer, and their team at the California Law Review edited the piece. Professors Stephen McGeorge Bundy, Jesse H. Choper, Paul J. Mishkin, and Dan Rodriguez commented on earlier drafts and taught me the legal concepts that underlie this paper. Rebecca Bratspies, David Gossett, Doni Gewirtzman, Julie Jauregui Holloway, Anne Johnson, 
line of attempts to use court-approved remedies to resolve mass tort injury claims. ${ }^{2}$ The Court upheld the Court of Appeals for the Third Circuit's decision to vacate the certification of a class created "for settlement purposes only." The class would not have been certifiable for litigation purposes. Toward the end of the majority opinion, the Court suggested that, although the federal courts could not approve settlement for the class in Windsor, Congress had the power to enact a legislative version of the agreement. ${ }^{4}$

The Court's dictum in Windsor raises an interesting issue regarding the different capabilities of the legislature and the judiciary to resolve mass tort cases. Since mass tort litigation first appeared in the 1970s, litigants have sought relief through the courts. Although scholars disagree about whether the judicial system has adapted well to meet the demands of mass tort litigation, ${ }^{5}$ the system has continually modified the ways in which it addresses the ongoing tide of suits. The Court's opinion in Windsor reminds us that courts may craft innovative remedies for mass tort claims, but limitations exist on the judicial power. ${ }^{6}$

Molly Peterson, and Sherri Sokeland all provided support and critical feedback on drafts. Finally, 1 would not have written this paper without the constant guidance of Judge William A. Fletcher. Despitc a full teaching schedule, BarBri lectures, and an embattled judicial nomination, he never closed his door to me. This Comment is for my dad, Luis G. Bianchini, who taught me long ago to use academic rigor to support my social theories.

The Securities and Exchange Commission, as a matter of policy, disclaims responsibility for any private publication or statement by any of its employees. The views expressed herein are those of the author and do not necessarily reflect the views of the Commission or of the author's colleagues at the Commission.

1. 117 S.Ct. 2231 (1997). For a complete discussion of the issues resolved in Windsor, see Part III.A.2, infra.

2. See infra Part II.

3. See Georgine v. Amchem Prods, Inc., 83 F.3d 610, 624 (3d Cir. 1996) (stating that "aithough class actions may be certified for settlement purposes only, Rule 23(a)'s requirements must be satisfied as if the case were going to be litigated").

4. The Court wrote:

The argument is sensibly made that a nationwide administrative claims processing rcgime would provide the most secure, fair, and efficient means of compensating victims of asbestos exposure. Congress, however, has not adopted such a solution. And Rule 23 ... canuot carry the large load [the defendants], the class counsel, and the District Court heaped upon it.

Windsor, $117 \mathrm{~S}$. Ct. at 2252.

5. See, e.g., Deborah R. Hensler \& Mark A. Peterson, Understanding Mass Personal Injury Litigation: A Socio-Legal Analysis, 59 Brook. L. Rev. 961, 962-63, 1061 (1993); see also John A. Siliciano, Mass Torts and the Rhetoric of Crisis, 80 CORNELl L. REv. 990, 991-98 (1995) (arguing that issues commonly discussed as "uniquely difficult" in mass tort actions, such as causation, are not unique and in fact may be easier to resolve in large scale actions).

6. See Windsor, 117 S. Ct. at 2244 (basing its decision on an interpretation of Fcderal Rule of Civil Procedare 23 but noting that "Rule 23's requirenents must be interpreted in kceping with Article III constraints"); see also Richard L. Marcus, They Can't Do That, Can They? Tort Reform via Rule 23, 80 CORNELL L. REV. 858, 872-95 (1995) (discussing various constitutional questions raised by mass tort class actions); Roger H. Trangsrud, Mass Trials in Mass Tort Cases: A Dissent, 1989 U. ILL. L. REv. 69, 84-86 (1989) (arguing that trial judges faced with mass trials bend the rules to allow a mass trial and then try to cocrce settleinent). 
The legislature's power to develop solutions for mass tort claims is broader than that of the judiciary. To date, however, Congress has not enacted significant mass tort reform legislation. ${ }^{7}$ Possibly as a result of this inaction, scholarly literature has spent little time examining possible implications that congressional intervention might have for mass tort litigation, except to observe that Congress could act as an alternative forum for reform.

Recent events have provided a case study through which to examine how the legislature might confront the issues presented by mass tort litigation. On June 20, 1997, the attorneys general of forty states, together with major tobacco manufacturers, publicly announced that they had successfully negotiated a $\$ 368.5$ billion global settleinent agreement that would settle lawsuits pending against the tobacco industry. ${ }^{8}$ Although the attorneys general and the tobacco companies had negotiated and drafted this "Proposed Tobacco Industry Settlement"9 during the course of ongoing litigation, rather than seeking approval in the courts, the parties sought congressional approval. ${ }^{10}$ Such a request had the effect of asking Congress to intervene directly in a live judicial dispute and approve a reinedy, substituting a legislative solution for a judicial solution.

This Comment explores the implications of the Supreme Court's invitation in Windsor for Congress to take a role in mass tort reform by using the Proposed Settleinent to articulate differences between judicial and legislative treatinent of inass tort settlement issues. The Proposed Settleinent was umique: its drafters asked Congress to assume a "quasi-judicial" function by approving an agreement to settle ongoing litigation. Yet, despite having the elements of a settlement approved through the judicial process, this settleinent would have been a federal law. In order to have approved it, Congress would have had to pass legislation enacting it.

Once finalized, a congressionally approved settlement would be more difficult to challenge than one approved by a court. Two distinct bodies of law govern how courts conduct judicial review of judicial decisions and how they conduct judicial review of legislative decisions. Judicial review of judicial decisions contains two elements: substance and procedure. In contrast, judicial review of enacted legislation reviews only substance. Courts review general social and economic legislation only to determine whether the post-enactinent effects of the legislation place unconstitutional burdens on individuals. They presume that Congress follows a

7. See infra Part II.

8. See Jackie Calmes \& David Rogers, Clinton's Tobacco-Based Budget Puts GOP in Hot Spot, WALl ST. J., Jan. 16, 1998, at A16 (noting that the immunities provisions were the primary incentive for the tobacco industry).

9. Proposed Tobacco Industry Settlement, June 20, 1997 (visited Mar. 23, 1999) <http:// stic.neu.edu/settlement/6-20-settle.htm > [hereinafter "Proposed Settlement"].

10. See infra Part II. 
constitutionally sufficient procedure in passing legislation," and have declined invitations to invalidate laws based on assertions that the lawmaking process was flawed.12

The fact that the political process goes unreviewed raises special questions when the subject of the legislation is mass tort reform. Mass tort litigation is characterized by vast disparities in wealth that exist between large defendants and the individuals claiming injury against thein. The political process potentially allows these defendants an opportunity to influence congressional outcomes in ways that have direct and long-lasting impacts on the judicial system. ${ }^{13}$ Had Congress approved the Proposed Settlement, it would have enacted legislation significantly changing how courts adjudicate tobacco litigation in ways favorable to the tobacco industry. In addition, it would have affected the cases of millions of individuals. ${ }^{14}$ Regardless of whether the Proposed Settlement might have improved mass tort litigation procedures with respect to tobacco litigation, Congress would have reached this result in a transparently political way. In addition to drafting the settleinent, the tobacco industry spent millions of dollars lobbying for its passage. And, as the body of this Comment will argue, enactinent of the Proposed Settleinent would have resulted in an outcoine unattainable through a judicial settlement because a court would likely have invalidated the agreement for failing to protect the interests of all whoin it bound.

By examining the Proposed Settlement, this Comment discusses the possibility that large-scale defendants will use the political process to achieve inodifications of the judicial structure, thus guaranteeing outcones

11. "The Constitution presumes that, absent some reason to infer antipathy, even improvident decisions will eventually be rectified by the democratic process and that judicial intervention is generally unwarranted no matter how unwisely we may think a political branch has acted." Federal Communications Comm'n v. Beach Communications, Inc., 508 U.S. 307, 313 (1993); Vance v. Bradley, 440 U.S. 93, 97 (1979).

12. See, e.g., United States R.R. Retirement Bd. v. Fritz, 449 U.S. 166 (1980) (upholding retroactive application of a statute to pensioners despite claims that the legislation had been mischaracterized before Congress).

13. Both political science and legal scholars have discussed the influence special interest groups have on the political process. See, e.g., Daniel A FARBer \& Philip P. Frickey, LAw ANd Public CHOICE 132-43 (1991); Einer R. Elhauge, Does Interest Group Theory Justify More Intrusive Judicial Review?, 101 YALE L.J. 31, 35-44 (1991).

14. At the time the state attorneys general and the tobacco companies drafted the Proposed Settlement, lawsuits had been filed, in both state and federal courts, covering all nicotine dependent people or their survivors in the United States. Bob Van Voris, Castano II: A Tobacco Class Action Revived, NAT'L L.J., June 9, 1997, at A6. In addition, union insurance funds, following the lead of the states, liad filed class actions in 28 states, representing as many as 23 million claims. Enactment of the Proposed Settlement would have affected those cases. Bob Van Voris, Funds Seek Payback: Unions Sue over Tobacco-Related Health Expenses, NAT'L L.J., Oct. 27, 1997, at A1. See also Brian Cummings, Class Action Here Hits Tobacco Accord, Chic. DaIly L. Bull., July 7, 1997, at 1; Samuel Maull, Big Tobacco Hit with Class Action in N.Y. After 5 Suits Consolidated, DAlly ReC., Oct. 31, 1997, at 31. 
that they would not necessarily achieve through the judicial process. This Comment asks whether Congress or the courts are in a better position to prevent these outcomes. Deciding that only Congress can accommodate the concerns raised, it makes a few recommendations for the principled legislator to consider in evaluating mass tort litigation reform promoted by mass tort defendants imvolved in ongoing hitigation.

This Comment procecds as follows. Part I provides the specific context for the rest of the Comment, setting forth the settlement provisions of the Proposed Settlement and giving a short history of tobacco litigation, the specific events that resulted in the Proposed Settleinent, and the agreement's ultimate demise in Congress. Part II reviews the history of mass tort reforin generally. It suggests that the Proposed Settlement is one of many proposals seeking legislative relief for the problems of mass tort litigation.

The rest of the Comment uses the terms of the Proposed Settlement as a prisin to isolate differences between the ways that the judicial and legislative branches might address mass tort issues. It also discusses implications these differences might have for legislative solutions to mass tort problems. Part III analyzes the Proposed Settlement using existing doctrines of judicial review as analytical tools. First, it looks at the Proposed Settlement as a court of law might review a class action settlement. Next, it reviews the Proposed Settlement as if Congress had approved the agreement and it was subsequently challenged in court. This Part concludes that the Proposed Settlement likely would have been declared constitutional. It observes that Congress could pass as legislation a settlement that would likely be invalidated in the courts. Part IV explores the implications of the result arrived at in Part III and provides recommendations. It suggests that Congress has the power to undermine core concepts of judicial integrity by passing judicial reform legislation heavily influenced by special imterests. Finally, it suggests some minimum considerations that Congress should keep im mind when it deliberates on mass tort reform litigation. ${ }^{15}$

I

\section{The Proposed Tobacco Industry Settlement}

The terms and conditions of the Proposed Settlement, the history that led to their creation, and their lifespan in Congress form the starting point for this discussion. Explicating the settlement terms clarifies the agreeinent, which is the poimt of reference for this Comment. Understanding the

15. Some will ultimately ask whether the issues discussed in this Comment are any different from the issues of special interest group influence in other areas of legislation. I believe they may be, because Article III of the U.S. Constitution creates a unique area of overlap betwcen the legislative and judicial branches that occurs when Congress considers judicial reform legislation. In addition, because defendants in mass tort litigation may be entire industries, they have an ability to affect the political process in ways that others cannot. This issue is a topic unto itself and is not explored further in this Comment. 
evolution of tobacco tort litigation may explain why the tobacco companies promoted the Proposed Settlement in Congress. Finally, examining how the tobacco industry's lobbying efforts may have affected congressional deliberations shows the interaction between special interest groups and Congress. Taken as a whole, this Part provides the specific context for the more general discussions that follow.

\section{A. The Settlement Terms of the Proposed Settlement}

The Proposed Settlement is a document consisting of ten Titles and eight Appendices, most of which created restrictions on the tobacco industry through proposed regulations. These restrictions fell mainly into three parts. First, the tobacco companies agreed to undergo federal regulation by the Food and Drug Administration (FDA). ${ }^{16}$ Second, the tobacco companies agreed not to challenge a number of restrictions on their advertising. ${ }^{17}$ Third, the tobacco companies assumed the burden of reducing underage smoking in the United States. ${ }^{18}$ Also, they agreed to pay $\$ 368.5$ billion to the states. ${ }^{19}$

In addition to these restrictions, the Proposed Settlement was intended to resolve ongoing litigation. The settlement provisions in Title VIII of the Proposed Settlement restructured the rules governing tort litigation for all pending and future claims against the tobacco industry. These provisions minimized exposure to liability in both the short and long term. One provision settled all lawsuits filed by state or local governments, most pending class action lawsuits, and all individual suits based on claims of addiction or dependency. ${ }^{20}$ All class action and other procedural aggregation devices were to be banned, ${ }^{21}$ forcing all claims against tobacco industry defendants not settled in the agreement to be brought individually. ${ }^{22}$ The agreement additionally prohibited evidence that a tobacco company had produced "reduced risk" products when such evidence was offered to prove defendants' knowledge of tobacco's health dangers. ${ }^{23}$ This prohibition would

16. See Proposed Settlement, supra note 9, tit. I. Note that the Fourth Circuit recently held that the FDA did not have statutory authority to regulate tobacco. See Brown \& Williamson Tobacco Corp. v. Food \& Drug Admin., 153 F.3d 155 (4th Cir. 1998), reh'g en banc denied, 1998 U.S. App. LEXIS 28,409 (4th Cir. Nov. 10, 1998). It is unclear whether this ruling would have affected the Proposed Settlement, given that the settlement might have been interpreted as congressional expansion of the FDA's jurisdiction.

17. See Proposed Settlement, supra note 9, tits. I.A. \& III.

18. See id. tit. V.

19. See id. tit. VI.

20. See id. tit. VIII.A.1. Most of the pending lawsuits not specifically settled would have been those filed by third party payors, whose claims were exempted from resolution under Title VIII, but who still would have been affected by the disaggregation requirements. See id. tit. VIII.A.2.

21. See id. tit. VIII.B.2.

22. See id.

23. See id. tit. VIII.B.7. Currently, Federal Rule of Evidence 407, which bars the admission of certain remedial measures taken by companies as evidence of negligence, prevents plaintiffs from 
have blocked access to millions of documents that contain previously unreleased information about tobacco products and their associated health risks. ${ }^{24}$

Over the long term, tobacco companies' exposure to tort liability would have been minimized. First, all claims of tobacco addiction and dependency would have been banned, prohibiting an entire class of potential lawsuits. ${ }^{25}$ Second, the Proposed Settlement eliminated recovery of punitive daniages. ${ }^{26}$ Third, the agreement capped the total amount of money that the tobacco conipanies would have to pay to claimants in any one year. ${ }^{27}$

In short, the agreement would have stopped existing lawsuits and deterred future suits. As for those claims that could be brought, the elimination of pumitive damage awards and procedural aggregation devices would have niade individual litigation less likely. Without the promise of sizable attorneys' fees from large-scale nuass tort litigation, attorneys would be less likely to accept claims against the tobacco industry. ${ }^{28}$ In addition, a pool of potentially damaging evidence against the tobacco industry could not be used. Taken as a whole, the agreement effectively neutralized tobacco tort litigation.

\section{B. A Brief History of Tobacco Tort Litigation}

Although, standing alone, parts of the Proposed Settlement may seem confusing or make little sense, when viewed in the aggregate against the history of tobacco tort litigation, the settlement was a clear response to changing patterns of litigation. These changes promised an uncertain litigation future for an industry with a forty-year history of litigation success. The progression of tobacco tort litigation and the events leading up to the

introducing evidence of product improvements as proof of negligence or strict liability, but only if such changes are made following an injury. Improvements made before injury has occurred are allowable into evidence. See FED. R. EvID. 407. The evidentiary bar drafted in this agreement would have been broader than the current federal rule.

24. See Proposed Settlement, supra note 9, app. VIII

25. See id. tit. VIII.A.1.

26. See id.

27. The cap would have been an amount equal to approximately $33 \%$ of the annual payments made to the government. See id. tit. VIII.B.9-11. At its zenith, the industry was to pay to the states $\$ 15$ billion per year. See id. tit. VI. Therefore, it would have been liable for up to $\$ 4.95$ billion in private recovery.

28. Examining Victim Compensation and Attorneys' Fees Before the Subcomm. on Administrative Oversight and the Courts of the Senate Comm. on the Judiciary: Hearings on Class Action Lawsuits, 105th Cong. (1997) (testimony of John C. Coffee, Jr., Adolph A. Berle Professor of Law, Columbia University Law School) [hereimafter "Coffee Testimony"]. For a general discussion of the attorneys' fee issue, see Bruce L. Hay, The Theory of Fee Regulation in Class Action Settlements, 46 AM. U. L. REv. 1429 (1997) (discussing the use of a fee cap to prevent attorneys' fees from encouraging attorneys to settle against the interests of their chents). See also infra Part III.A. 
Proposed Settlement have been discussed in detail elsewhere. ${ }^{29}$ The following Section provides only a brief overview to place the Proposed Settlement in context.

\section{Patterns of Litigation Predating the First State Tobacco Lawsuits}

Scholars writing on the history of tobacco tort litigation have broken it down into three "waves," each representing different plaintiffs' litigation strategies. With each advancing "wave," plaintiffs moved closer to litigation success. The most recent wave, one of class actions combined with lawsuits filed by the attorneys general of most states, threatened to wash away the tobacco industry - a result the industry was eager to avoid.

"Wave One" marked the start of tobacco tort litigation. It began in the mid-1950s following the release of the first reports attempting to link cigarette smoking to cancer. ${ }^{30}$ Based on claims of negligence and breach of warranty ${ }^{31}$ these cases failed because they could not overcome the tobacco industry's strongest argument: unforeseeability. Because tobacco compamies had learned of the potential health dangers associated with cigarettes only recently, the industry could not be held liable for harming smokers. ${ }^{32}$

"Wave Two" tobacco litigation comcided with the rise of mass tort litigation in the 1970s. In this wave, the tobacco companies used a "free will" defense, arguing that smokers always had the option to quit and failing to do so amounted to contributory negligence. Their argument was strong; with the passage of the Federal Cigarette Labeling and Advertising Act (FCLAA) ${ }^{33}$ in 1965, all cigarette packaging and advertising had to display prominent warnings about the dangers of tobacco. ${ }^{34}$ Without research establishing that cigarettes were addictive, and in light of public awareness that smoking was dangerous to one's health, juries consistently held that smokers had assumed the risk of their habit and ruled in favor of the tobacco companies. ${ }^{35}$

Throughout Waves One and Two, industry defendants exploited the large financial disparity between themselves and individual plaintiffs. ${ }^{36}$

29. See generally Carrick Mollenkamp et al., The People vs. Big Tobacco (1998); Graham E. Kelder, Jr. \& Richard A. Daynard, The Role of Litigation in the Effective Control of the Sale and Use of Tobacco, 8 STAN. L. \& POL'Y REV. 63 (1997).

30. See Robert L. Rabin, A Sociolegal History of the Tobacco Tort Litigation, 44 Stan. L. Rev. 853,856 (1992). Rabin notes that the first study actually appeared in the Journal of the Medical Association (JAMA) in 1950, but did not gain popular acceptance until Reader's Digest published an article on the topic in 1952. See id. at 855.

31. See id. at 859 .

32. See id. at $858-61$.

33. 15 U.S.C. $\S \$ 1331-1341$ (1994).

34. See Richard A. Daynard \& Graham E. Kelder, Jr., The Many Virtues of Tobacco Litigation: In the Failed Global Settlement, the Tobacco Industry Almost Freed Itself from the Civil Justice System, TRIAL, Nov. 1998, at 34.

35. See id.

36. See Rabin, supra note 30 , at 857 ; Kelder \& Daynard, supra note 29, at 71-72. 
Taking advantage of their financial superiority, the tobacco companies would wage "wars of attrition," wasting down the plaintiffs' resources im discovery. A well-known articulation of this strategy stated:

The aggressive posture we have taken regarding depositions and discovery in general continues to make these cases extremely burdensome and expensive for plaintiff's lawyers.... To paraphrase General Patton, the way we won these cases was not by spending all of [our] money, but by making that other son of a bitch spend all of his. ${ }^{37}$

Personal injury lawyers who represented individual plaintiffs were consistently outmatched by the tobacco companies' vast resources.

Things began to change in the early 1990s. In "Wave Three," tobacco litigation evidence taken from internal documents became available. ${ }^{38}$ This evidence suggested that tobacco products were harmful and addictive, ${ }^{39}$ that the industry had known this for decades, and that tobacco companies chose to exploit their knowledge of cigarettes' addictiveness in order to sell more products. ${ }^{40}$ For the first time, plaintiffs appeared to have the relevant evidence necessary to bring viable cases against the indnstry. In addition, private attorneys began to pool resources and file aggregated suits against the mdustry. ${ }^{41}$ It appeared that plaintiffs were finally in a position to mount successful lawsuits against the tobacco industry.

\section{The State Tobacco Suits and the Proposed Settlement}

Pressure on the tobacco companies increased even further when the states began to initiate lawsuits alleging injury caused by the tobacco companies. In May 1994, the office of the Attorney General for the State of Mississippi filed a lawsuit agamst multiple cigarette companies, including Corr-Williauns, The American Tobacco Company, R.J. Reynolds, Brown and Williamson, Phillip Morris, and the Liggett Group. Mississippi sought to recover Medicaid funds it had paid to support the medical costs of

37. Haines v. Liggett Group, Inc., 814 F. Supp. 414, 421 (D.N.J. 1993) (quoting an internal memorandum by J. Michael Jordan, attorney at R.J. Reynolds).

38. See Tucker S. Player, Note, After the Fall: The Cigarette Papers, the Global Settlement, and the Future of Tobacco Litigation, 49 S.C. L. REv. 311, 321-29 (1998) (discussing the discovery of this information).

39. See Kelder \& Daynard supra note 29, at 76 (citing a February 25, 1994 letter from FDA Commissioner David Kessler stating that the FDA had received "mounting evidence" that "the nicotine ingredient is a powerfully addictive agent").

40. See Player, supra note 38 , at 321-29.

41. See Rabin, supra note 30 , at 858,865 . This breakthrough case was filed originally in 1988 and eventually spawned a major Supreme Court opinion on cigarettes and state preemption issues. See Cipollone v. Liggett Group, 505 U.S. 504 (1992); Castano v. American Tobacco Co., 84 F.3d 734 (5th Cir. 1996) (describing a nationwide class consisting of "all nicotine dependent persons" in the United States). 
indigent smokers. ${ }^{42}$ The suit sparked a tidal wave of state lawsuits against the tobacco imdustry. By mid-1997, forty of the fifty state attorneys general had filed suit against tobacco companies. ${ }^{43}$

The state plaintiffs' theories of liability differed from case to case. They included equitable theories of unjust enrichment and restitution, ${ }^{44}$ state statutory causes of action such as antitrust conspiracy and consumer fraud, ${ }^{45}$ and federal causes of action under RICO ${ }^{46}$ The theme of each case, however, was similar: the payment of medical costs for illnesses related to tobacco use had directly harmed the state. Therefore, tobacco companies were liable to each state.

In 1996, the litigation picture looked very different than it had ten years earlier. Rather than defending against individual plaintiffs, the tobacco industry faced a nationwide class action ${ }^{47}$ and civil actions filed by states. These plaintiffs were well financed and had evidence against the defendants in the form of industry documents and testimony of whistleblower tobacco company employees. ${ }^{48}$ In other words, the tobacco industry faced the real possibility of losing high-profile, enormously expensive court battles. The 1997 Proposed Settlement was an attempt to return

42. See In re Corr-Williams Tobacco Co., 691 So. 2d 424, 426 (Miss. 1997); In re Fordice, 691 So. 2d 429, 431 (Miss. 1997). The Proposed Settlement would have prevented resolution of an interesting side issue generated by Fordice, the governor of Mississippi. In his official capacity, Fordice filed a petition with the Supreme Court of Mississippi for mandamus or prohibition to prevent the attorney general from proceeding with the suit. He argued that the governor's office had jurisdiction over the Division of Medicaid; therefore, the attorney general lacked the authority to file a lawsuit without approval from the governor's office. See id. at 430-31. The court declined to issue a writ, refusing to "act as a trial court regarding this issue." Id. at 434 . The tobacco companies later filed for a writ of mandamus or prohibition with the court to require the chancery court to dismiss the attorney general's suit on the same grounds. See In re Corr-Williams Tobacco Co., 691 So. $2 d$ at 425 . The court refused to grant mandamus and stated that the question whether the attorney general properly had power to sue could "adequately be decided by this Court on appeal on the merits." Id. at 427; see also infra Part III.A. (parens patriae discussion).

43. Although these suits were settled in the $\$ 206$ billion settlement that the attorneys general and the tobacco companies signed following the failure of the Proposed Settlement in Congress, see, e.g., Berry Meier, In a New Attempt, States Unveil a Proposed Tobacco Settlement, N.Y. Times, Nov. 17, 1998, at A1; Sundra Torry \& John Schwartz, States Approve \$206 Billion Deal with Big Tobacco; Industry Retains Key Marketing Devices, WASH. PoST, Nov. 21, 1998, at A1, people interested in locating the original suits will find them at the State Tobaeco Information Center (STIC) website: <http://www.stic.neu.edu/summary.htm> (visited Jan. 6, 1999). This website contains complete information about many aspects of the state attorneys' general suits against the tobacco industry.

44. See, e.g., McGraw v. American Tobacco Co., No. CIV.A. 94-C-1707, 1995 WL 569618 (W. Va. Cir. Ct. June 6, 1995) (settled); Moore v. American Tobacco Co., No. 94-1429 (Miss. Ch. filcd May 23, 1994) (settled).

45. See, e.g., Minnesota v. Philip Morris, Inc., No. CX-95-2536, 1995 WL 862582 (Minn. Ct. App. Dec. 26, 1996) (settled).

46. See, e.g., Texas v. American Tobacco Co., Civ. No. 5:96-CV-0091 (E.D. Tex. filcd Mar. 28, 1996) (settled).

47. See Castano v. American Tobacco Co., 84 F.3d. 734 (5th Cir. 1996); supra note 43.

48. See, e.g., Tobacco Whistleblower Says Ex-Boss Lied, CNNfn, (Jan. 26, 1996) <http:// www.cnnfn.com/news/9601/26/wigand/index.htmi>. 
tobacco tort litigation to the point it had been at in the early 1980 s-i.e., comprised of small, individual lawsuits without highly probative evidence needed to establish liability.

\section{The Proposed Settlement in Congress}

In November 1997, following weeks of Senate committee hearings that had taken place during the previous summer, ${ }^{49}$ Senator McCain announced legislation replicating the terms of the Proposed Settlement. ${ }^{50} \mathrm{Al}-$ though passage of the Proposed Settlement was never certain, ${ }^{51}$ the McCain bill initially appeared likely to pass. ${ }^{52}$ The tobacco industry wasted no time in launching one of the costliest lobbying campaigns in history to achieve swift passage of the deal. On top of a combined $\$ 13.79$ million it contributed to congressional campaigns in 1996 and $1997,,^{53}$ the industry hired influential lobbyists and prepared to spend $\$ 20$ million in a public advertising campaign to guarantee that the legislation passed. ${ }^{54}$ By mid-January, President Clinton appeared convinced that tobacco legislation would pass in 1998, and based 60 percent of his proposed spending budget for the following five years on new tobacco revenues. ${ }^{55}$

Congress characterized the legislation as a bill desigued to stop children froun sinoking, ${ }^{56}$ but the tobacco industry was not motivated by similar public health concerns. From the outset, the tobacco industry made one issue clear: it would only support a legislative version of the Proposed Settlement that retained the settlement provisions negotiated in the original

49. See Review of the Global Tobacco Settlement Hearings Before the Senate Judiciary Committee, 105th Cong. (1997).

50. The McCain bill was entitled The Universal Tobacco Settlement Act, S. 1415, 105th Cong. (1997). Orrin Hatch also presented a similar bill, S. 1530, 105th Cong. (1997), which referred to itself as "[a] bill to resolve ongoing tobacco litigation, to reform the civil justice system responsible for adjudicating tort claims against companies that manufacture tobacco products, and establish a national tobacco policy for the United States that will decrease youth tobacco use and reduce the marketing of tobacco products to young Americans." 143 CoNG. REC. S12,574, S12,575 (daily ed. Nov. 13, 1997). The McCain version was the bill that gained support in the Senate, however.

51. See Agreement Still Seems Far Away, Associated Press Pol. Service, Nov, 9, 1997, available in 1997 WL 2561434.

52. See Jeffrey Taylor \& Suein L. Hwang, From the Ashes: The Big Tobacco Deal Gains New Momentum Despite Early Setbacks, WaLl ST. J., Oct. 23, 1997, at A1.

53. See id. These figures only include the first 6 months of 1997.

54. See Maureen Dowd, Editorial, Political "Dream Team" Shuck Integrity to Lobby Tobacco Deal, SAN ANTONIo ExPREss-News, Dec. 27, 1997, at 5B (criticizing Ann Richards, George Mitchell, and Howard Baker for lobbying on behalf of the Proposed Settlement); Peter H. Stone \& James A. Barnes, The Tobacco Industry Mulls an Ad Blitz, NAT'L J., Dec. 20, 1997, at 2565 ("The television and print blitz could cost as much as $\$ 20$ million, which would make the effort one of the priciest public advocacy campaigns ever.").

55. See Calmes \& Rogers, supra note 8, at A16.

56. See Clinton Hopeful on Tobacco Deal, CHI. TRIB., Jan. 14, 1998, at 1 ("A growing majority of Congress seems to agree that as a matter of public health policy we need to stop kids from smoking.") (quoting White House spokesman Mike McCurry). 
document. ${ }^{57}$ As the tobacco advertising clearly stated, "[I]f the settlement contained no benefits for our industry, or threatened the very existence of our operations, we could not accept it. ${ }^{\text {"58 }}$ Nonetheless, beginning with the release of damaging evidence that the R.J. Reynolds Tobacco Company, creator of the well-known character "Joe Camel," had targeted children as young as thirteen, congressional leaders began to balk at supporting the industry's interests. They feared that widespread public awareness of the tobacco compamies' unpalatable conduct would make congressional support of the settlement provisions politically difficult.5 In March, the Senate drafters withdrew the settlement provisions of the Proposed Settlement. ${ }^{60}$

Eliminating the settlement provisions removed the tobacco industry's only reason for promoting tobacco legislation. Reversing its position, it spent new millions to convince Congress to withdraw its support of the tobacco legislation. The industry achieved its goal swiftly. On June 17, 1998 , unable to gain the required sixty votes to end debate and move to a final vote, the bill returned to committee-a result that effectively killed it. ${ }^{61}$ With a fimal price tag totaling $\$ 40$ million, the tobacco industry had not achieved the legislation it wanted, but it had managed to prevent the legislative process from arriving at an undesired outcome. In its obituary for the legislation, the New York Times characterized the bill's history in the following way:

The prospect of a comprehensive tobacco settlement seemed something historic that would forever change the ways cigarettes were marketed in the United States and alter the nation's public health and regulatory landscape.... In return, the [tobacco] companies would have received protection fron1 a wave of court cases against them. But that pact turned out to have a Perils-ofPauline existence in large part because of the impression that after decades of political dominance, big tobacco was on the ropes. ... When Mr. McCaim and his Commerce Committee took up the effort to draft the bill last wimter, the political tide seemed to be running strongly against the tobacco industry and Republicans were running scared. ... So ... the committee produced a measure

57. See Koop Opposes Immunity in Tobacco Deal, CH1. TruB., Jan. 14, 1998, at D12 ("The industry has steadfastly insisted that it would withdraw its support for any piece of legislation that does not include the settlement's protections from class-action lawsuits.").

58. Print Advertisement, The Tobacco Settlement: What's in it for you? What's in it for us? (visited Feb. 23, 1999) <http://www.tobaccoresolution.com/hot/wh_init.htm>. This was part of a print campaign that began in March 1998 in major newspapers throughout the United States. See also Samuel Goldreich, Big Tobacco: Limited Liability Firms Won't Sign Without Immunity, WASH. TimES, Mar. 12, 1998, at B7.

59. See Charles Pope, Slow Burn over Settlement, Seatrle Times, Jan. 16, 1998, at A2.

60. See David E. Rosenbaum, Senate Is Offered Sweeping Measure to Fight Smoking, N.Y. TMES, Mar. 31, 1998, at A1.

61. See David E. Rosenbaum, Senate Drops Tobacco Bill with '98 Revival Unlikely; Clinton Lashes Out at G.O.P., N.Y. TIMEs, June 18, 1998, at A1. 
that was even tougher on tobacco.... At that point tobacco walked out. ... . ${ }^{62}$

In walking out, the tobacco industry demonstrated that it still had political clout. Diminished status as a powerful lobby notwithstanding, the mdustry had convimced a majority of the Senate to vote against the very bill legislators had originally advocated as a way to help prevent youth smoking.

\section{III}

\section{The Troubled History of Mass Tort Reform}

The pending litigation that faced tobacco companies largely explains why the industry aggressively pursued a legislative solution to resolve lawsuits brought against it. That the companies resorted to the legislature is not umque; rather, it is part of a larger pattern in the field of mass tort litigation. Mass tort litigation has presented problems for the courts. Legislative solutions promise to help resolve some of these issues because Congress has the power not only to suggest, but also to miplement institutional reform. To date, however, the search for mass tort litigation reform has been troubled. Proposals have been batted back and forth between the legislature and the courts without resolution. Thus, it was perhaps mevitable that a major defendant would seek a direct legislative solution to resolve its judicial woes.

\section{A. The Beginnings of Mass Tort Litigation and the Difficulties of the Mass Tort Class Action}

Prior to the advent of modern day mass tort litigation, tort litigation was best characterized as "private rights" litigation, ${ }^{63}$ or dispute resolution between two adverse parties. Beginning in the 1970s, however, the nature of tort litigation began to change. Large numbers of people injured after use of or exposure to the sanie products or circumstances filed lawsuits. ${ }^{64}$ The resulting civil actions tested the limits of a traditional paradigm whereby two adverse parties resolved their dispute before a smgle judge. ${ }^{65}$

62. Id.

63. For a discussion of the development of "public rights" and "private rights" litigation, see Richard H. Fallon et al., HaRt and Wechsler's The Federal Courts and The Federal System 78-92 (4th ed. 1996); Abram Chayes, The Role of the Judge in Public Law Litigation, 89 HARV. L. Rev. 1281, 1282-84 (1976).

64. Yandle v. PPG Industries, Inc., 65 F.R.D. 566 (1974), an early asbestos case, was one of the first attempts to bring snit under the class action rule. The conrt found that the class failed the superiority and predominance requirements of Federal Rule of Civil Procedure 23(b)(3) and did not certify the class. In addition to class actions, many courts addressed cases and claims consolidated under 28 U.S.C. $\$ 1407$ (1993). Becanse the use of consolidation to adjudicate mass tort claims is a topic that would form the basis of another law review article, I do not address it in the text.

65. See generally Chayes, supra note 63 (discussing how the judicial system was evolving from its traditional model of providing one-time remedies for past imjuries between two parties imto a "public law" model, issuing ongoing decrees to govern future conduct of inultiple parties). 
Unlike the purely private, two-party dispute, these tort suits were brought on behalf of thousands of people suffering injuries and sharing only one clearly common characteristic: they had all been exposed to or used an identifiable product or chemical. Often, few other variables remained the same from claimant to claimant. They had been exposed in different places, at different times, and for different lengths of time. The injuries sometimes differed im imtensity or were different injuries altogether.

Some suits were brought under Federal Rule of Civil Procedure 23, which governs class action litigation. ${ }^{66}$ Although the rule had been revised in 1966 to expand the kinds of class action lawsuits allowed into court, it was not designed with the modern mass tort in mind ${ }^{67}$ Its provisions were intended to provide aggregation procedures for suits brought by multiple, similarly situatcd claimants or for claims common to large numbers of lawsuits not otherwise similar enough to justify aggregating the suits themselves. ${ }^{68}$ Without a class suffering from substantially similar harms, it was difficult to justify treatment as a class action under the revised 1966 rule. Nonetheless, plaintiffs' bar attorneys, possibly driven by the fact that the disparate injuries suffered appeared to stem from sources common to an entire class, developed imcreasmgly complex trial strategies and novel legal applications in attempts to keep these cases before the courts. ${ }^{69}$

These lawsuits met with limited success. In theory, the judicial system offered two options to litigants prosecuting tort claims. They could proceed with their suits individually or they could employ aggregation devices. In

66. Federal Rule of Civil Procedure 23 reads in pertinent part:

(a) Prerequisites to a Class Action. One or more members of a class may sue or be sued as representative parties on behalf or all only if (1) the class is so numerous that joinder of all members is impracticable, (2) there are questions of law or fact common to the class, (3) the claims or defenses of the representative parties are typical of the claims or defenses of the class, and (4) the representative parties will fairly and adequately protect the interests of the class.

FED. R. CIv. P. 23(a).

67. The advisory committee note from the proposed 1966 revision of Rule 23 has been cited often to support this observation:

A "mass accident" resulting in injuries to numerous persons is ordinarily not appropriate for a class action because of the likelihood that significant questions, not only of damages, but of liability and defenses to liability, would be present, affecting the individuals in different ways. In these circumstances an action conducted nominally as a class action would denigrate in practice into multiple lawsuits separately tried.

Fed. R. Crv. P. 23 advisory committee's note.

68. See id. ("Subdivision (b)(3) encompasses those cases in which a class action would achieve economies of time, effort, and expense, and promote uniformity of decision as to persons similarly situated, wihhout sacrificing procedural fairness or bringing about other undesirable results."); Spenccr Williams, Mass Tort Class Actions: Going, Going, Gone?, 98 F.R.D. 323, 325-28 (1983).

69. See Linda S. MULLEnIX, Mass Tort Limigation at v (1996) ("[M]ass tort litigation, with its distinctive characteristics, began to emerge only in the 1980s."); Stephen McG. Bundy, The Policy in Favor of Settlement in an Adversary System, 44 HASTINGS L.J. 1, 26 nn.105-06, 27 (1992) (noting that in 1960 products liability torts totaled less than $2 \%$ of all diversity tort claims filed compared with $10.5 \%$ in 1975 and an estimated 30\% in 1986); Peter H. Schuck, Mass Torts: An Institutional Evolutionist Perspective, 80 CORNELL L. REv. 941,945 (1995). 
reality, the litigants faced a judicial system weighted toward individual litigation. ${ }^{70}$ For those seeking class treatment, the procedural barriers of Rule 23 made certification difficult. ${ }^{71}$

The failure to gain class certification hurt plaintiffs, defendants, and the legal system. From the plaintiffs' perspective, failure to gain class certification meant either that the individuals in the class would have to litigate their claims on a case-by-case basis, or that they would have to reorganize imto smaller classes and attempt to gain certification for the new classes. For defendants, defending multiple lawsuits was potentially very expensive, to the point of threatening large companies with bankruptcy. ${ }^{72}$ Fimally, from the judicial perspective, case-by-case litigation threatened to flood court dockets.

On the other hand, even successful certification had disadvantages. A successfully certified class action could lead to a highly segmented and

70. The litigation history and ultimate bankruptcy of A.H. Robins Company illustrates the dangers that the pre-settlement era held for defendants. In 1989, the United States Court of Appeals for the Fourth Circuit approved a class action and settlement brought by a plaintiff class against Aetna Casualty and Surety, the insurer to A.H. Robins, manufacturer of the Dalkon Shield. See In re A.H. Robins Co., Inc., 880 F.2d 709, 710 (4th Cir. 1989). In its opinion, the Fourth Circuit traced the unfortunate litigation history that ultimately led to Robins' bankruptcy and the suit against Aetna then before the court. Many classes filed suit against Robins. All ultimately failed to meet class certification requirements. The first action was filed in New York state court. See id. at 712-13. The second action was filed in the Northern District of California, which certified the class only to have the certification vacated by the Ninth Circuit. See In re Northern Dist. of Cal. Dalkon Shield IUD Prods. Liab. Litig., 693 F.2d 847 (9th Cir. 1982). In 1984, Robins itself sought class certification of the claims for punitive damages in all Dalkon Shield cases in the Eastern District of Virginia. See In re Dalkon Shield Pumitive Damages Litig, 613 F. Supp. 1112 (E.D. Va. 1985). On appeal, certification was denied. See In re A.H. Robins Co., 880 F.2d at 715. Although attempts at class certification were failimg, individuals continued to file against Robins. Verdicts against the manufacturer grew. The first verdict ever rendered against Robins was filed in a state court in Kansas in 1975. See id. At that time, the plaintiff received $\$ 85,000$. See id. In 1985 , a plaintiff represented by the same counsel who had won against Robins in 1975 received a $\$ 9.1$ million award. See id. at 711. Bankruptcy and the Fourth Circuit's approval of the class settlement in In re A.H. Robins fmally reheved the corporation of its financial burdens.

71. In addition to the requirements of Rule 23(a), most mass tort class actions are litigated under Rule 23(b)(3), which requires the court to take into account the following factors when deciding whether to grant certification: the interest of members of the class in individually controlling the prosecution or defense of separate actions, the extent and nature of any litigation concerning the controversy already commenced by or against members of the class, the desirability or undesirability of concentrating the hitigation of the claims in the particular forum, and finally, the difficulties likely to be encountered in the management of the class action. See FED. R. CIV. P. 23(b)(3). Many of the famous attcmpts at class certification have stumbled on these requirements. See, e.g., Valentino v. CarterWallace, Inc., 97 F.3d 1227 (9th Cir. 1996) (decertifying class claiming against manufacturer of an epilepsy drug in part for failure to meet Rule 23(a)(3)-(4) requirements); Castano v. American Tobacco Co., 84 F.3d 734 (5th Cir. 1996) (decertifying nationwide class consisting of "all nicotine dependent persons" in the United States in part on predominance grounds); In re American Med. Sys., Inc., 75 F.3d 1069 (6th Cir. 1996) (decertifying class claiming against manufacturer of penile implants for lack of commonality); see also Linda S. Mullenix, Class Resolution of the Mass Tort Case: A Proposed Federal Procedure Act, 64 TEx. L. REv. 1039, 1041-43 nn.11-15 (1986) (listing failed mass tort suits).

72. See supra note 70. 
complex trial. ${ }^{73}$ Moreover, defendants feared the massive lump sum judgments certain to result in the event a class succeeded on its claims. Mass tort litigation, regardless of form, simply challenged the conventional litigation process. Members of the legal community began to search for nonjudicial ways to improve the system.

\section{B. Attempts at Legislative Reform}

The late 1980s and early 1990s saw a number of different proposals aimed at creating external reform. All shared a common theme: they targeted the legislature. Both the American Law Institute (ALI) and the American Bar Association (ABA) explored the problem of mass tort litigation. The ALI began two projects: a comprehensive project assessing the state of the personal mjury tort system $^{74}$ and a complex litigation project that resulted in a number of statutory recommeudations. ${ }^{75}$ The ABA issued a report intended to aid Congress in providing a legislative means through which to address mass tort litigation. ${ }^{76}$ The judiciary also became involved through the Ad Hoc Committee on Asbestos Litigation (the Reavely Committee), which Chief Justice Rehnquist appointed in 1990 to imvestigate the problems arising from mass tort asbestos litigation. The committee issued a report in 1991 recommending that Congress resolve the asbestos situation via legislation. ${ }^{77}$

Congress itself directly addressed issues important to mass tort litigation. In 1988 Congress authorized the Federal Courts Study Center to study litigation in the federal courts and to issue recommendations. ${ }^{78}$ In addition, Congress debated several bills that would have achieved punitive damages reform, to no avail. ${ }^{79}$ None of the legislative reform proposals garnered enough support to pass. ${ }^{80}$

73. See Bundy, supra note 69 , at 27.

74. AMERICAN LaW INST., ENTERPRISE ResponsibiLTtY FOR PERSONAL INJURY (1991).

75. American Law Inst., Complex Litigation: Statutory Recommendations and ANALYSIS (1994).

76. American Bar Assoc., Comm'n on Mass Torts, Report to the House of Delegates (1989)

77. Judicial CONFerence of the UNited States, Report of the Judicial CONFERENCE AD Hoc Commttree on Asbestos Lmigation (1991), reprinted in Asbestos Litig. Rep. (Andrews Pub.) (Mar. 14, 1991) 22,698.

78. See MuLlenIX, supra note 69 , at $\mathrm{X}$.

79. Members of Congress have repeatedly introduced and diseussed legislation for general mass tort reform. There was a proposal included in the Omnibus Bankruptcy Act of 1992, S. 1985, 102d Cong. (1992), which went through the Senate but brought no discussion in the House. In 1994, Seuator Danforth introduced the Multiple Puuitive Damages Faimess Act, S. 2537, 103d Cong. (1994). In 1995, a produets liability bill, H.R. 956, 104th Cong. (1995), was attempted. In 1996, Senator Hatch introduced a punitive damages act, S. 671, 104th Cong. (1996). At the start of the 1997 term he made the following plea as he introduced the Multiple Punitive Damages Fairness Act of 1997, S. 78, 105th Cong. (1997), which was identieal to the 1996 bill: "I introduced identieal legislation last Congress... . I hope that we can move this bill in the 105th Congress." 143 Cong. REC. S379-01 (daily ed. Jan. 22, 1997). Most recently, last July, the Senate ended the possibility of reform when 47 


\section{The Settlement Class: Emphasis Returns to the Judiciary}

While tort reform fouudered in Congress, the class action certified under Rule 23 for settlement purposes only (as opposed to litigation purposes) emerged as an innovative way to resolve mass tort claims. ${ }^{81}$ Nicknamed the "settlement class," a class action "certified for settlement purposes" gives the parties an opportunity to negotiate a private resolution to a lawsuit before seeking certification. ${ }^{82}$ Under Rule 23(e) or its state court equivaleut, ${ }^{83}$ a court may accept this solution by approving the settlement. The judicial approval allows the settlement to carry the same res judicata consequences as if the case had been fully litigated to a final judgment. In seeking certification "for settlement purposes only," attorneys saw a way to resolve litigants' claims on an efficient class basis while avoiding the problenıs of litigating mass tort cases ${ }^{84}$ Initial feedback on settlement classes was favorable euough that a proposed revision of Rule 23 explicitly provided for settlement classes, even in cases where the class was not certifiable for litigation purposes. ${ }^{85}$

Euthusiasm for settlement classes eventually waned. Despite promising a new and successful way to resolve mass claims, ${ }^{86}$ negotiations on behalf of settlement classes sometimes resulted in collusive agreements.

senators refused to cut off debate to actually vote on the bill. See Philip Buchan, Products Liability Bill Killed in Senate, Trial, Sept. 1998, at 11.

80. A bill did reach the Senate floor, the Multiparty, Multiforum bill that recommended modifications of 28 U.S.C. $\S 1407$ to allow consolidated trial of multiparty, multiclaim cases after transfer and consohidation, but it was defeated. See MULLENIX, supra note 69, at X.

81. The Dalkon Shield bankruptcy agreement was the first "settlement class," see supra note 70, but quickly spread into other contexts. See John C. Coffee, Jr., Class Wars: The Dilemma of the Mass Tort Class Action, 95 Colum. L. Rev. 1343, 1380 (1995).

82. Id. at 1377 .

83. See Herbert B. Newberg, Newberg on Class Actions app. 13-2. (2d ed. 1985).

84. See, e.g., Richard B. Schmitt, The Dealmakers: Some Firms Embrace the Widely Dreaded Class Action Lawsuit, WALL ST. J., July 18, 1996, at A1 (discussing the use of settlement classes to bind plaintiffs and avoid case-by-case hitigation).

85. See Judicial Conference of the United States, Committee on Rules of Practice AND Procedure, Report of THe AdVISORY COMMITIEe on CiVIL Rules, 167 F.R.D. 539, 551-55 (1996) (advisory committee on the proposed revisions of Rule 23). Interestingly enough, objections existed at the time of the proposed revisions that settlement classes would encourage class counsel to "take a dive and sell res judicata," $i d$. at 552, but such objections did not overcome the proposal to allow certification of settlement classes that could not be litigated in court. See id. at 551 (discussing the addition of a Rule 23(b)(3)(H), "the opportunity to settle on a class basis claims that could not ... be litigated by [or against?] a class as comprehensive as the settlement class'). The Advisory Committee has subsequently placed these revisions "somewhere between on-hold and permanent deep freeze," and "there will not be an explicit amendinent for some time to come." Telephone Interview with Edward Cooper, Reporter, Advisory Committee for the Proposed Revisions to Rule 23 (Oct. 12, 1998).

86. See generally Deborah R. Hensler, A Glass Half Full, a Glass Half Empty: The Use of Alternative Dispute Resolution in Mass Personal Injury Litigation, 73 TEx. L. REv. 1587 (1995); Judith Resnik, Procedural Innovations, Sloshing Over: A Comment on Deborah Hensler, A Glass Half Full, a Glass Half Empty: The Use of Alternative Dispute Resolution in Mass Personal Injury Litigation, 73 TEx. L. REv. 1627 (1995). 
Class counsel won sizable fee awards and defendants escaped potentially crushing liability. Plaintiffs, however, did not benefit enough, if at all. ${ }^{87}$ As one federal appellate court noted, settlement agreements "primarily serve the interests of defendants-by granting expansive protection from law suits-and of plaintiffs' counsel-by generating large fees gladly paid by defendants as a quid pro quo for finally disposing of many troublesome claims." ${ }^{88}$ Moreover, courts presented with these settlements often approved them, giving defendants the added benefit of res judicata. ${ }^{89}$

In response, the Supreme Court issued its opinion in Windsor, advising federal courts to be wary of approving settlement class agreements. ${ }^{90}$ The Court rejected the settlement class, at least in part, and left the field of mass tort litigation open for the next round of reform attempts. Additionally, the Court observed that the judiciary's power to create solutions to mass tort lawsuits is limited. ${ }^{91}$

Because of the limits on judicial power, emphasis could return to congressional solutions for problems of class actions. ${ }^{22}$ Even if this does not become the case, this sketch of the history of mass tort reform shows that parties have sought and will continue to seek legislative solutions. Therefore, even though Congress has not yet passed comprehensive mass tort reform, it is inportant to understand the inplications that legislative remedies might have for mass tort litigants.

III

\section{Legislative SetTlement Versus Judicial Settlement}

Through its settlement provisions, the Proposed Settlement would have been a legislatively approved settlement to ongoing litigation. Although the document was drafted by adverse litigants, rather than subjecting it to judicial approval once agreement was reached, which is the

87. See Coffee, supra note 81, at 1373-85; Susan P. Koniak \& George M. Cohen, Under Cloak of Settlement, VA. L. REv. 1051 (1996) (discussing collusive settlements); Susan P. Koniak, Feasting While the Widow Weeps: Georgine v. Amchem Products, Inc., 80 CoRnell L. Rev. 1045, 1115-26 (1995) (discussing the inadequacy of judicial review of class action settlements).

88. In re General Motors Corp. Pick-Up Truck Fuel Tank Prods. Liab. Litig., 55 F.3d 768, 778 (3d Cir. 1995).

89. As Professor Coffee has noted, the class action certification process began to conflate the notion of certification into scttlemcnt. Judges simply used the existence of an agreement to serve as dispositive proof that the class was certifiable. See Coffee, supra note 81, at 1377.

90. See John C. Coffee, Jr., After the High Court Decision in Amchem Products v. Windsor, Can a Class Action Ever Be Certified Only for the Purpose of Settlement?, NAT' L L.J. July 21, 1997, at B4. (suggesting that the tobacco agreement was sent to Congress in anticipation of the Court's decision in Windsor); see also infra Part III.

91. See supra note 6 and accompanying text.

92. At the end of July 1998 , Congress passed a bill exempting from liability the suppliers of raw materials for medical implants, which is evidence of the ongoing attcmpts to seek judicial relief via the legislature. See Jim Puzzanghera, Medical Implant Makers Breathing a Sigh of Relief, SAN Jose MerCuRy News, Aug. 1, 1998, at C1. 
judicial procedure for class action settlements filed in both state and federal courts, ${ }^{93}$ the negotiators stepped into the legislative arena. Through this unprecedented move, the states and the tobacco companies sought legislative resolution of a problem origmally brought before the judiciary. The Proposed Settlement, therefore, provides a vehicle for examining the implications that arise from having the legislature solve mass tort claims instead of the judiciary.

This Part analyzes the effects substitution of a legislative solution for a judicial one might have created. Using the process of judicial review as it is followed by federal courts, ${ }^{94}$ this Part explores differences between the two branches of government. It first analyzes the Proposed Settlement as if the parties had initially submitted the agreement to a court, rather than the legislature. Next, it looks at the settlement as if Congress had ratified the agreement and it was subsequently challenged in court. In other words, it first analyzes the agreement as a judicial settlement, and then as a legislative settlement.

As a judicial settlement, it is unlikely that the tobacco agreement would have been approved. Class action litigation raises special difficulties in protecting a "fair" adjudicative process. The Constitution requires that an injured individual be a participant in his or her own lawsuit. ${ }^{95}$ With a class, one attorney represents inany injured people at the same time. The possibility always exists that because class inembers are not in the same position as litigants in individual actions, the class counsel will fail to protect class interests. ${ }^{96}$ Recognizing this, the federal class action rule explicitly requires that any class approved for litigation purposes meet a number of criteria before proceeding. ${ }^{97}$

The protections provided in the formal litigation process do not disappear when a dispute between adverse parties ends in settlement rather than judgment. Class action settlements require formal judicial approval. Currently, federal courts are required to scrutinize classes seeking judicial approval for settlement purposes so as to uncover agreeinents that fail to benefit class members. Such scrutiny is intended to reveal problems of inadequate representation and conflicts of imterest, both of which infringe on the individual protections that the traditional "private" model of litigation

93. All states with class action statutes contain a provision drawn from Rule 23(e) which forbids dismissal of a class unless the court has approved the settlement agreement. See NEWBERG, supra note 83, at app. 13-2.

94. As a result of the Supreme Court's opinion in Windsor, Rule 23 reqnires higher levels of scrutiny than do state class action rules.

95. See infra Part IV.

96. Of course, in class tort litigation, even individuals represented by attorneys may fall prey to manipulation in ways not experienced by ordinary tort plaintiffs. See Coffee, supra note 81, at 1373-74 (discussing "imventory" claims).

97. See FED. R. Civ. P. 23, supra note 66. 
tries to assure. ${ }^{98}$ When looking at the Proposed Settlement as a court would, the agreement manifests flaws that would likely be sufficient to mvalidate it under the criteria set forth for evaluating class action settlements.

In contrast, when looking at the Proposed Settlement as a settlement approved by the legislature, it quickly becomes obvious that the Proposed Settlement would withstand judicial scrutiny, even though it contains the same flaws that would mvalidate it had the drafting parties sought judicial approval in the first instance. The considerations important to a court in evaluating a judicial settlement carry little weight in evaluating a legislative settlement. A legislative settlement is a statute; courts generally decline to look at the process through which statutes are enacted.99 The Constitution entrusts each of the coordinate branches with policing its internal processes; therefore, the courts guarantee only that the litigation process, not Congress's lawinaking process, meets constitutional standards. They review congressional statutes only to assess whether the law imposes unconstitutional burdens on individuals.

Because courts will use different levels of scrutiny depending upon whether an agreement is a judicial or a legislative settleinent, the form in which the agreement appears in court may determine its final fate. As a judicial settlement, a court would have been likely to invalidate the Proposed Settlement on statutory or constitutional grounds. As a statute, however, a court would have been likely to uphold it. Given that the same agreeinent leads to opposite outcomes on judicial review depending on its form, the question becoines what, if anything, should be done to accommodate judicial priorities when the legislature resolves mass tort claims.

\section{A. Judicial Settlement}

In binding the imterests of all public and private litigants in the United States with claims against the tobacco industry, the Proposed Settlement resolved claims for a de facto class. Had a court reviewed the agreement as a class settleinent, it likely would not have approved it. Both the academic literature and judicial opinions have discussed how to evaluate whether a settlement offers an effective alternative to litigation without depriving litigants of the protections offered to them in a formal judicial proceeding. Applymg these criteria to the Proposed Settlement, it becomes apparent that the agreement manifested flaws that would have been fatal if it had been subject to judicial scrutiny.

98. See infra Part III.A.

99. See supra note 11 . 


\section{Conflicts of Interest in Settlement Class Action Lawsuits}

As noted briefly in Part II, supra, settlement agreements soinetimes mask conflict of interest problenns. Conflicts in class actions primarily occur in two forms. The first arises between class claimants whose claims or injuries differ from one another. When the claims of the individual class inembers are different, the cohesiveness of the class itself is not certain. This is largely because divergent interests often conflict with one another. In the litigation context, courts will deny certification of such classes because class ineinbers' claims are insufficiently similar to justify class treatment. ${ }^{100}$

The second conflict occurs between the class and the class counsel. ${ }^{101}$ Large attorneys' fees give class counsel a financial interest to settle that is independent of the class claimants' interests. When the attorneys' interests diverge from those of the class, the resulting settlement agreement nay enrich class counsel and minimize defendants' costs, but provide little, if any, recovery for the class members. ${ }^{102}$

Both forms of conflict can appear in a mass tort action. First, a class nay not be cohesive. The claimants in a mass tort suit must maintain that they have all suffered injuries resulting froin exposure to or use of defendants' product(s). The type and severity of the injuries will differ from claimant to claimant. Moreover, the etiology of disease differs from person to person, so inass tort injuries may appear in different people at different points in time. The total pool of possible claimants includes not only people who are currently manifestimg injuries that may be linked to use of or exposure to a product, but also those who will inanifest injuries at some point in the future. The interests of those currently injured and those who have not yet inanifested clinical symptons of disease, however, conflict. If recovery is naximized today, then people who are not yet hurt will be disadvantaged relative to the total victim pool. ${ }^{103}$ "Exposure-only" plaintiffs ${ }^{104}$

100. See FED. R. Crv. P. 23(b)(3) (commonality requirement); Mullenix, supra note 71.

101. See, e.g., Coffee testimony, supra note 28.

102. See, e.g., Broin v. Philip Morris, Inc., Case No. 91-49738CA(22) (visited Jan. 6, 1999) $<$ http://www.tobaccoresolution.com/statesettlement/bromst01.html> (settlement agreement providing the class with no financial recovery); In re General Motors Corp. Pick-Up Truck Fuel Tank Prods. Liab. Litig., 55 F.3d 768. (3d Cir. 1995) (Plaintiff class received coupons worth $\$ 1000$ toward the purchase of a new pick-up truck that had to be redeemed within in a 15 month period. The claimants who challenged the class did so on the following grounds: (1) the settlement did nothing to fix the trucks that the plaintiffs were currently using; (2) the $\$ 1000$ did little to defray the actual cost of purchasing a new pick-up truck, making use of the coupons unrealistic for many class members; and (3) the fifteen-month redemption period was not long enough for government claimants to redeem their coupons. Nonetheless, class couusel originally received $\$ 9.5$ million for drafting the agreement. See id. at 781-82.).

103. This is actually the result that the system produces without any settlement at all. Some people manifest injuries later than others. If the initial litigation onslaught bankrupts the defendant, then later generations will be without compensation entirely. Nonetheless, from the standpoint of 
have an interest in obtaining relief for the entire range of injuries or having recovery maximized at a later time. If both groups of claimants form a single class, the resulting conflicts may make it noncertifiable. ${ }^{105}$

Second, because mass tort cases are litigated on a contingency fee basis, attorneys have significant incentives to settle. Reaching settlement guarantees that class counsel will receive fees for their services. Rather than face the uncertainties of litigation, including the possibility that the class will not be certified for litigation purposes, class counsel can earn millions of dollars by settling. Moreover, with their own financial interests at stake, class counsel may be less aggressive in challenging settlement terms favored by defendants. Clients' interests in maximizing recovery, which a settlement might not accomplish, thus diverge from the interests of their attorneys in collecting fees through settlement. A mass tort class action, therefore, may suffer both from conflicts within the class itself and from conflicts of interest between attorneys and the class.

Conflicts of interest, however, do not actually cause the problems found in settlement classes. Problems arise when negotiators downplay or ignore existing conflicts and seek court certification "for settlement purposes only," looking to bind as many potential claimants as possible under the doctrine of res judicata. ${ }^{106}$ In doing so, plaintiffs' attorneys fail to provide "adequate representation" to their clients. ${ }^{107}$ Courts compound this failure when they certify a conflict-ridden settlement class under the auspices of Rule 23(e) or its state court equivalents. In addition, where the settlement agreement binds an entire class that includes future interests, individuals with ripe claims in the future nnay find that the availability of judicial recourse for their injuries has been restricted or eliminated. ${ }^{108}$ Over

adequate representation, to maximize recovery for future interests, future classes still need to be represented when lawyers negotiate a global settlement.

104. See Amchem Prods., Inc. v. Windsor, 117 S. Ct. 2231, 2244 (1997) (diseussing "exposureonly" plaintiffs).

105. This was the issue in Windsor. An aside to this discussion is whether future interests can ever be represented in federal courts, given the possible limitations on such litigants under the standing doctrine contained in Article III of the U.S. Constitution. Some assert that a class with "cxposure-only" plaintiffs violates Article III because not all of the claims before the court would be currcntly ripe. See Windsor, $117 \mathrm{~S}$. Ct. at 2244 (1997) (stating the objectors' argument that "the procecding is a nonadversarial endeavor to impose on countless individuals without currently ripe claims an administration compensation regime binding on those individuals if and when they manifest injuries"). This discussion is beyond the scope of the Comment. For a discussion of this issue, see Jeremy Gaston, Note, Standing on Its Head: The Problem of Future Claimants in Mass Tort Actions, 77 TEx. L. REv. 215 (1998) (arguing that standing should always be denied to future interest plaintiffs).

106. See generally Brian Wolfman \& Alan B. Morrison, Representing the Unrepresented in Class Actions Seeking Monetary Relief, 71 N.Y.U. L. REv. 439 (1996) (arguing that current class action rules do not provide adequate protection for class members whose interests differ from those of the class representatives and class attorneys, and proposing amendments).

107. See FED. R. CIV. P. 23(a) (requirement of adequate representation).

108. Bound claimants could challenge a class that has already been certified and approved. They could attack the class as violating the Article III "case and controversy" requirement. See supra note 
the long term, therefore, a collusive class settlement hurts both the claimants who are members of a class certified for settlement purposes and later generations of claimants bound by the agreement.

\section{Amchem Products v. Windsor: Tightening Judicial Scrutiny of Settlement Class Action Lawsuits}

Recognizing that courts were approving settleinent agreements containing conflicts of interest under a lower standard of scrutiny than that given to litigation classes, the United States Supreme Court ratcheted up the level of scrutiny that federal courts nust apply to settlement class certification under Rule 23(e). On June 25, 1997, the Court issued its opinion in Amchem Products $v$. Windsor, ${ }^{109}$ a case that questioned whether a putative class could be certified for settleinent purposes, even though it would not have been certified for litigation purposes. In Windsor, a coalition of asbestos manufacturers and plaintiffs' attorneys had brokered a settlement that "would provide an alternative resolution mechamism for asbestos claims,' including claims that might be filed in the future."110 After completing the agreement, the parties initiated a class action in the District Court for the Eastern District of Pennsylvania solely to gain certification as a settlement class. ${ }^{11}$

Writing for the majority, Justice Ginsburg noted that the "settlement only" class had become a "stock device" to resolve class action disputes, ${ }^{112}$ but cautioned that settlement classes should be subject to close judicial inspection. ${ }^{113}$ The Court stated that a district court would not have to ask whether a class action would present "intractable management problems" if litigated, ${ }^{114}$ because a successful settlement prevents a trial. ${ }^{115}$ In a critical passage, however, the Court observed that the "other specifications of the rule-those designed to protect absentees by blocking unwarranted or overbroad class definitions-delnand undiluted, even heightened, attention in the settlement context."116 Applying this scrutiny to the settlement class, the Court held that certification had been unwarranted. ${ }^{17}$

105. They could also challenge the class on due process grounds, discussed infra in Section 4 of this Part.

109. 117 S. Ct. 2231 (1997).

110. Id. at 2238 (quoting Georgine v. Amchem Products, Inc., 83 F.3d 610 (3rd Cir. 1996)).

111. See id. at 2239.

112. See id. at 2247 .

113. See id. at 2248 .

114. See FED. R. CIV. P. 23(b)(3)(D).

115. See Windsor, 117 S. Ct. at 2248.

116. Id. The Court's opinion reads the certification requirements of the existing Rule 23 so as to avoid reaching constitutional questions. During oral arguments, opponents of the settlement class had raised a number of constitutional objections to the settlement class. Opponents had argued that the settlement was not a justiciable case or controversy for Article III purposes, that the "exposure-only" claimants in the class lacked standing to sue, and that settling claims for "clients" who had manifested no symptoms, precluding them from bringing suit at a later date, had due process implications. The 
The Windsor opinion focused on protecting class members. Its investigation of the Rule 23(a) and Rule 23(b) requirements of predoininance, ${ }^{118}$ typicality, and adequacy of representation ${ }^{119}$ suggests that the Court was trying to make lower federal courts aware that lawyers seeking certification for settlement purposes might present to the courts settlement agreements that ignore conflicts of interest. The message of Windsor, therefore, is that a court must scrutinize the provisions of both Rule 23(a) and (b)(3) closely before it certifies a class for settlement purposes under Rule 23(e).

\section{Scrutinizing the Proposed Settlement as a Settlement Class Action}

How would the Proposed Settlement have fared if it had been scrutinized for conflicts of interest and adequacy of representation? Under the standards currently existing for the federal judiciary, it would appear to fail scrutiny.$^{120}$ Reviewing the agreement for potential conflicts, it is questionable whether the people who negotiated and drafted the Proposed Settlement adequately represented the interests of the individuals that the document would have bound. ${ }^{121}$

Court avoided the constitutional questions because they "would not exist but for the class action certification." Id. at 2244 (quoting Georgine v. Amchem Products, Inc., 83 F.3d 610, 623 (3d Cir. 1996)).

117. See id. at 2249-52.

118. See id. at 2250 .

119. See id. at 2250-51. The opinion states that the inquiry for adequacy of representation under Rule 23(a) "serves to uncover conflicts of interest between named parties and the class they seek to represent." Id. at 2250 . In addition, the Rule 23(a) requirentent also examines class counsel for competence and potential conflicts of interest. See id. at 2251 n. 20 .

120. The Windsor requirements only apply to claims brought under Rule 23 and therefore do not apply to class actions brought in state courts. Whether settlements failing to meet the Windsor requirements brought in state courts would violate the Constitution remains an open question.

121. It is possible that the terms of the Proposed Settlement actually reflected the merits of the various claims resolved by the agreement. At the time the state attorneys general and the tobacco companies announced the Proposed Settlement, the tobacco companies had not paid any money to conipensate smokers or third-party payors. See Proposed Settlement, supra note 9, Preamble. Therefore, to the extent that the agreentent allowed individual, case-by-ease litigation to continue, it may not have harmed non-state tort litigants. Moreover, the evidentiary restrictions, while more extensive than those found in Federal Rule of Evidence 407, might have been created to encourage the tobacco companies to produce public health information rather than to prevent individuals from using important evidence in trial.

I discount this possibility for the following reasons. First, non-state litigants were not represented during the negotiations. Second, the agreement would have settled then-existing elass actions, whieh might have had the effect of barring most currently injurcd smokers front pursuing individual suits because the then-existing class actions were so comprehensive that they bound those interests. Third, the agreement eliminated punitive damages recovery for private suits.

On this last point, the academic literature on settlements has discussed a "shadow effeet" that pending litigation has on settlement recoveries. The fear of trial drives up the value of settlements, regardless of the actual merits of the case. See generally Robert H. Mnookin \& Lewis Kornhauser, Bargaining in the Shadow of the Law: The Case of Divorce, 88 YALE L.J. 950 (1979) (ereating the "shadow" metaphor). This fear has been especially prevalent in cases with the possibility of punitive damages awards. See Thomas Koenig, The Shadow Effect of Punitive Damages on Settlements, 1 Wis. L. Rev. 169, 172 (1998); cf. Herbert M. Kritzer \& Frances Kahn Zemans, The Shadow of 


\section{a. Unequal Terms Found in the Proposed Settlement}

On its face, the Proposed Settlement should have sparked further scrutiny. Its terms bound private, non-state litigants but provided no benefits to those parties. All direct financial recovery would have gone to the states. Some of the money was intended for public health purposes, but the agreement did not specify how the money was to be used. ${ }^{122}$ Although funds could have been spent for the benefit of current smokers and people exposed to smoke, thus providing an indirect benefit, the agreement did not require such expenditures and therefore did not directly provide relief to mdividual claimants.

In addition, the agreement contained a trade-off between current and potential litigants. All pending personal injury litigation would have been "resolved" or "settled" by the Proposed Settlement. These are euphemistic terms. Individuals involved in litigation would have lost their claims. In contrast, those who had not filed suit as of the effective date of the agreement or were not bound as class members in cases settled in the Proposed Settleunent would have had the opportunity to bring individual suits in the future. ${ }^{123}$ Therefore, potential litigants would have retained the option to hitigate against the tobacco companies, but current litigants would have lost that option.

Third, future claimants and third-party payors retained the ability to bring suit, but the agreement hindered their ability to litigate. By prohibiting consolidation of individual claims, ${ }^{124}$ the agreement inhibited large insurance interests from efficiently pursuing reimbursement claims for money paid on behalf of millions of insureds. The agreement also expressly estopped individual claimants from using evidence released by the tobacco coinpanies on "reduced risk" tobacco products, ${ }^{125}$ evidence that might otherwise have supported negligence or strict liability theories. ${ }^{126}$

Punitives: An Unsuccessful Effort to Bring It into View, 1 WIS. L. REv. 157, 167 (1998) (arguing the effects of punitive daniages on settlements are not certain). Therefore, if the tobacco companies had acted like other corporate defendants fearing judgment and individual claims, they would have provided direct recovery for private litigants. However, to the extent the companies managed to eliminate punitives entirely and obtain other modifications to the process through which courts address tobacco claims, the results of the tobacco negotiations appear best explained by the absence of any advocates for individual litigants.

122. Title VII of the Proposed Settlement specifically suggests that Congress should mount a $\$ 1.5$ billion program to assist current smokers, but the agreement does not indicate how this suggested program is to be funded. See Proposed Settlement, supra note 9, tit. VII.

123. The provision allowing future litigants to bring suit may have been less meaningful than it appeared on its face. Because so many comprehensive class actions were pending in the courts, it is unclear how many claimants would have been left unbound by the agreement. The agreement left open the possibility of individual suits, but in practice may have ended up barring, by res judicata, such later suits.

124. See Proposed Settlement, supra note 9, tit. VWI.A.2; VWI.B.

125. See id. tit. VII.B.7.

126. See supra note 23. 
The language of these provisions alone, therefore, would have raised questions regarding the protection of all the interests bound by the agreement. Both the tobacco company defendants and the states benefited from the Proposed Settlement, but other bound interests appear not to have gained any benefit $\mathrm{m}$ exchange for what they forfeited.

\section{b. The Bound Parties}

Looking behind the terms of the Proposed Settlement for conflicts of interest would have revealed conflict between the bound parties. The Proposed Settlement was written to bind three identifiable sets of interests: (1) each of the fifty states, (2) all people in the United States who otherwise would have had a private claim against the tobacco industry for past, present, or future financial and physical injuries sustained from exposure to and use of tobacco products, and (3) all private insurers, who, like the states, have reimbursement claims against the industry. ${ }^{127}$ These interests are not cohesive, however, and would have conflicted.

The most visible conflict was the financial tension that existed among the various claimants. The states wanted to maximize their recovery for amounts spent treating people suffering from tobacco-related health problems. Private insurers wanted to receive their share of the reimbursement fund. Private litigants wanted the chance to maximize their personal recoveries against the tobacco industry for injuries sustained. Because three distinct sets of financial interests existed on the claimant side, the Proposed Settlement is startling in that it only accounted for one of those three interests.

A second conflict within the class existed between present interests and future interests. Pending litigation revolves around the currently injured. The focus of the Proposed Settlement, however, was to prevent the nation's youth froin smoking. ${ }^{128}$ Preventing future generations from smoking promotes public health and decreases the amount of money spent to treat smoke related illnesses, but does nothing for those currently involved in litigation. In addition, future litigants would have retained the power to sue, but current litigants would not. ${ }^{129}$ The Proposed Settlement thus favored future generations and shortchanged the interests of current smokers, exposed individuals, and private insurance companies.

\section{c. Conflicts of Interest Between Class Counsel and Individual Litigants}

The counsel who negotiated and drafted the Proposed Settleinent consisted of the collective state attorneys general, a few plaintiffs' attorneys, and the attorneys representing the tobacco companies' interests. The

127. See Proposed Settlement, supra note 9, tit. VII.A.

128. See, e.g., id. Preamble.

129. See supra Part I.A. 
drafters did not, however, appear to have represented the bound interests adequately. First, the attorneys general may not even have had the power to negotiate a settlement that bound private, non-state interests. Second, the private attorneys may have ignored conflicts that existed among their chents and between themselves and their clients. Were that the case, then the Proposed Settlement would have resulted from a process that failed to meet judicial standards of adequate representation for a settlement agreement.

\section{i. The Attorneys General May Have Exceeded the Bounds of Their Parens Patriae Authority}

The attorneys general who drafted the tobacco agreement were likely without power to grant the tobacco industry all of the concessions contained in the document. In settling, they acted as representatives not only of the states, but also of all private litigants with existing or future claims agamst the tobacco industry in the United States. They could have justified these actions only if the attorneys general validly exercised their power to represent their citizens. Individual plaintiffs were not otherwise represented in the negotiation and drafting process. ${ }^{130}$ The doctrine of parens patriae, however, which justifies state representation of citizens' claims, is not broad enough to have supported the attorneys' general actions in creating the agreement.

The term parens patriae refers to the power of a state to bring a lawsuit on behalf of its citizens. It stems from the British common law doctrine of parens patriae, which required the King to act as guardian for those deemed incompetent to protect themselves, primarily children and the mentally incompetent. ${ }^{131}$

The United States' courts have recogmized a broader parens patriae power than that found in Britain. In addition to the traditional parens patriae responsibilities, American courts have allowed states to bring lawsuits im cases that implicate the "quasi-sovereign interest" of the state. The term "quasi-sovereign interest" is not well defined, but generally has been found to exist when the state has suffered direct economic impact on its economy, or when the public is suffering generally from a harm and no simgle plaintiff suffers a loss large enough to justify a lawsuit economically or would have standing to sue imdividually to seek redress for the harm. ${ }^{132}$

130. See Bob Van Voris, Tobacco Negotiations Created Sharp Client Conflicts, NAT'L L.J., Aug. 4, 1997, at A8 ("I]ndividual plaintiffs were not represented in any formal way ....").

131. Literally translated, parens patriae ineans "parent of the country." See generally George B. Curtis, The Checkered Career of Parens Patriae: The State as Parent or Tyrant?, 25 DE PAUL L. REV. 895, 896-901 (1976).

132. See, e.g., Pennsylvania v. Nat'I Ass'n of Flood Ins., 520 F.2d 11 (3rd Cir. 1975) (standing denied in suit to recover for flood daunages to be paid to a common reimbursement fund), overruled in part by Pennsylvania v. Porter, 659 F.2d 306 (3d Cir. 1981); Minnesota v. RI-MEL, Inc., 417 N.W.2d 102, 111-12 (Mmn. Ct. App. 1988) (recognizing that the state may have a quasi-sovereign interest and 
Despite the amorphous boundaries of the parens patriae power, one specific limit on the doctrine exists: a state lacks the power to bring a lawsuit when it is "merely litigating as a volunteer the personal claims of its citizens." 133 When a state brings a claim as parens patriae, it must have an immediate and recognized interest that is independent of the citizens it represents in order to have power to bring suit. ${ }^{134}$ The state "must ... not merely seek redress for injury to private parties, who being real parties in interest, could themselves have prosecuted their own particular claims." 135

Private citizens have shown thentselves willing and able to assert tobacco tort claims. Citizens have filed private suits against the tobacco industry for decades. Individuals, classes of individuals, and the insurance companies that pay these individuals' medical costs have all filed suit. Even though suits to date have not resulted in successful judgments against the tobacco mdustry, they represent a flourishing field of private tort litigation. Therefore, there is no doubt that the real parties in interest can prosecute their own claims.

By attempting to resolve these private personal injury suits via the Proposed Settlement, the attorneys general breached the limits of their power ${ }^{136}$ and assumed the roles of private personal injury attorneys. Such conduct exceeds the scope of the parens patriae power. Since no other counsel settled the rights of private litigants at the timie that the Proposed

noting that individually harmed citizens "may not avail themselves of their remedy ... because of the economic burden of sumg on a small claim").

133. Pennsylvania v. New Jersey, 426 U.S. 660, 665 (1976) (discussing suit for injunctive and declaratory relief from New Jersey tax on non-residents). The limit on the parens patriae power stems from Article III itself. If a state, without more, could litigate claims on behalf of its citizens, then there would be no independent distinction between the meaning of the words "State" and "Citizen" in Article III $\$ 2$ of the Constitution. See id. at 665-66. Much of the parens patriae doctrine has been interpreted by federal courts. State courts bave incorporated the federal decisions into their own opinions; thus, federal interpretation of the doctrine in this field also accounts for state court interpretation.

134. See Pennsylvania v. West Virginia, 262 U.S. 553, 592 (1923) (finding standing to bring action enjoining West Virginia from enforcing a state statute that would eliminate the supply of natural gas that it provided to recipient states).

135. Id. See also Maryland v. Jonathan Logan, Inc., 482 A.2d 1, 6 (Md. 1984) ("[T]he state's parens patriae claim cannot be a disguised attempt to recover damages on behalf of the state's individual citizens-claimants.") (quoting Hawaii v. Standard Oil Co., 405 U.S. 251, 254 (1972)); Abrams v. New York City Conciliation and Appeals Board, 472 N.Y.S. 2d 839, 841 (N.Y. 1984) ("[W]hen the state does bring suit, it must be for redress of wrongs done to the interests of the people as a whole and not merely to vindicate the individual or private imterests of certain citizens."); Clark Oil \& Refining Corp. v. Ashcroft, 639 S.W.2d 594, 596 (Mo. 1982) ("[T] parens patriae action is not merely a suit on behalf of individual citizens prosecuting their private damage clains against other private individuals.").

136. Some attorneys general inay have been within their statutory authority to represent state citizens under state antitrust statutes containing parens patriae provisions allowing the state to seek recovery in place of individually injured parties. In addition, some would point out that the attorneys general drafted the Proposed Settleinent knowing that they would not be able to present the document in court. Even conceding these arguments, they do not address the further question whether the attorneys general could justify their initial decision to negotiate and settle purely private claims on a nationwide basis. 
Agreement was drafted and the attorneys general did not have the power to serve as counsel, the settlement provisions could not have been declared valid with respect to non-state imterests.

Even assuming that the attorneys general had the power to represent both state and private interests, they still failed to represent adequately all the imterests over which they had responsibility. As mentioned above, conflicts of interest existed between private litigants and the states, and between current and future interests. Yet the attorneys general did not seek outside counsel or take other action intended to prevent the conflicts from affecting the outcoine of the negotiation and drafting process. Without vigorous representation of all bound interests, the proprietary interest of the states ultimately outweighed other interests in the Proposed Settlement.

\section{ii. Plaintiffs' Attorneys}

A group of private attorneys assisted the attorneys general in drafting the Proposed Settlement. It appears that some of these attorneys who participated on trial teams assisting the attorneys general also represented private clients who were hitigating against the tobacco industry. ${ }^{137}$ Because the fimancial interests of the states and of the private litigants conflicted, the attorneys who represented both faced conflict of interest problems. At least some of them appear to have ignored these client conflicts. This left private interests effectively unrepresented. ${ }^{138}$

These conflicts were remediable. According to the rules of professional conduct, an attorney representing inultiple clients in a civil settlement may represent potentially competing interests if, after full disclosure of all the settlement terms, all of the clients consent to the representation. ${ }^{139}$ Although no evidence exists that the private attorneys ignored the rules of professional conduct with regard to client conflicts, it seeins unlikely that they sought their private clients' approval. No recovery went directly to non-state litigants. Rationally, it is highly unlikely that a private litigant seeking damages would have consented to a settlement agreeinent that provided no direct recovery. If these attorneys ignored imtraclient conflicts, such conduct not only wonld have failed the "adequate representation" requirements provided for in the class action rule, but also would have left

137. See Van Voris, supra note 130, at A8; Bob Van Voris, Mottley Sued: Was Client Sold Out? NAT'L L.J., Sept. 1, 1997, at A4 (regarding a \$1.5 billion lawsuit filed by a private claimant against an attorney who brokered Proposed Settlement).

138. See Van Voris, supra note 14, at A1 ("All of a sudden, we started reading in the newspapers about the possibility of a settlement, and we started hearing we were going to be cut out.' ... [T] [Teir fears of being cut out were justified." (quoting Steven E. Fineman, co-counsel for a group of umion insurers)).

139. See Model Rules of Professional Conduct Rule 1.8(g) (1995); Model Code of Professional RESPONSIBILITY DR 5-10 (1969). 
the attorneys subject to discipline for violating the rules of professional responsibility.

Additionally, the size of the attorneys' fees promised to the private attorneys created a large financial incentive for them to draft an agreement that the tobacco industry would sign. At the time that the Proposed Settlement was drafted, the private attorneys stood to receive up to twentyfive percent of any recovery. ${ }^{140}$ With the promised recovery totaling $\$ 368.5$ billion, these private participants would have received some $\$ 92$ billion for brokering the deal. The potential for such large financial reimbursement for the attorneys would have given them a direct fmancial incentive to broker a deal acceptable to tobacco interests. Because the tobacco industry made the settlement provisions the linchpin of the Proposed Settlement, ${ }^{141}$ the negotiating attorneys had an incentive to draft this section to favor the industry. This suggests that the interests of the private attorneys were in conflict with the interests of private litigants.

The tobacco agreement is rife with flaws when reviewed for conflicts of imterest and failure to provide adequate representation. The class interests conflicted with each other. No steps were taken to secure independent representation for these conflicting interests. The final agreement advantaged the drafting parties and failed to provide for bound interests left unrepresented during the drafting and negotiating process. Combined, these factors signal failure to meet the requirements needed for certification.

\section{Constitutional Issues: A Violation of Due Process}

Although the Proposed Settlement appears to have been negotiated and drafted im a manner that would have made it uncertifiable as a federal class action settlement, the possibility remains that it could have been certified. If it had been certified for settlement purposes, a bound individual could have challenged the res judicata effects. A colorable argnment exists that the agreement itself failed to provide constitutionally sufficient due process. ${ }^{142}$

In a court of law, a putative class member bound by an earlier judgment can challenge the res judicata effects of that earlier decision by

140. See Van Voris, supra note 130. A bill limiting these fees was introduced in the House of Representatives and hearings were held in December of 1997. See Limiting Attorneys Fees in the Global Tobacco Settlement Hearings Before the House Judiciary Subcommittee on Courts and Intellectual Property, 105th Cong. (1997). There is some question whether such an ex post limitation on fees would be constitutional. See Marcia Coyle, Cap on Tobacco Lawyers Fees Fought, NAT'L L.J., Dec. 22, 1997, at A9 (presenting arguments for and against constitutionality of such a bill).

141. See supra notes 57-58 and aecompanying text.

142. A post-certification challenge could be brought either in state court or fcderal court on due process grounds, whether the class was certified as a state class action or a federal class action. Bccause the Supreme Court has held that all class actions, state and federal, are bound to meet constitutional due process standards, even a class that was certified under state law could later be invalidated for violating constitutionally imposed minimum standards on the settlement process. 
arguing that the composition of the class violated due process. This principle was laid forth in Hansberry v. Lee. ${ }^{143}$ Its holding is clear: "[A] selection of representatives for purposes of litigation, whose substantial interests are not necessarily or even probably the same as those whom they are deemed to represent, does not afford that protection to absent parties which due process requires."144

The Supreme Court further articulated due process protections in Phillips Petroleum Co. v. Shutts. ${ }^{145}$ There, it applied the Fourteenth Amendment due process requirements articulated in Mullane v. Central Hanover Trust Company ${ }^{146}$ to class action challenges brought in state court:

If the forum State wishes to bind an absent plaintiff concerning a claim for money damages or similar relief at law, it must provide minimal procedural due process protection. The plaintiff must receive notice plus an opportunity to be heard and participate in the litigation, whether in person or through counsel. The notice must be the best practicable, "reasonably calculated, under all the circumstances, to apprise interested parties of the pendency of the action and affirm them an opportunity to present their objections." 147

Although no case has yet been tried challenging a class action settlement on procedural due process grounds, the principle underlying the Hansberry line of cases would appear to support such an extension. The cases allow a remedy for impermissible class composition after a court has judicially approved a class and overseen a final outcome regarding the class's rights. Because settlement classes, like litigation classes, require judicial approval and result in binding outcomcs, the issues raised in Hansberry and its progeny would appear to be the same whether a class was certified for litigation or settlement purposes.

The Proposed Settlement did not meet the due process requirements. It bound parties whose interests conflicted with one another. Absent parties whose interests were bound did not receive notice or an opportunity to participate in the drafting. The final docunnent provided less benefit to the unrcpresented interests than to the states. Under the holdings of Hansberry and Shutts, the settlement failed to meet constitutional minimums If

143. 311 U.S. 32 (1940). In Hansberry, a black couple who purchased property in a residential neighborhood challenged the applicability of racial covenants created by the sellers, which had been found valid in an earlier court decision. The Supreme Court reversed the Supreme Court of Illinois' holding that the couple was bound by res judicata even though their interests were adverse to the interests of those in the earher suit.

144. Id. at 45 .

145. 472 U.S. 797 (1985).

146. 339 U.S. 306 (1950).

147. Shutts, 472 U.S. at 811-12 (quoting Mullane, 339 U.S. at 314-15). 
certified as a settlement, the Proposed Settlement would have been found unconstitutional on post-certification review.

The above discussion demonstrates that the Proposed Settlement would have been invalid as a judicial settlement. The drafters failed to provide basic protections that the judicial system promises to all litigants. By ignoring those requirements, the drafters created a settlement that embodied the very flaws that courts currently are trying to expunge from class settlements.

\section{B. Legislative Settlement}

Had the Proposed Settlement been enacted into federal law, it would have been a legislative settlement subject to a different, less rigorous form of judicial review than that given to a judicial settlement. Applying this level of review to the Proposed Settlement as if it were an enacted law, it appears constitutional. Therefore, as a statute the Proposed Settlement would be valid, even while contaiming the same terms that would have prevented it from being approved as a judicial settlement. ${ }^{148}$

\section{Constitutional Challenges}

The Fifth Amendinent of the Uunted States Constitution initially appears to provide a constitutional ground upon which a litigant could have challenged an enacted statutory version of the Proposed Settlement. ${ }^{149}$

148. Reading this Section, some may note what appears to be an oversight. This Comment does not discuss possible separation of powers arguments. Had Congress enacted the Proposed Settlement, it would have intervened directly into ongoing litigation with the effect of dictating the outcomes of pending trials, which could be interpreted as intruding on the judicial function. Earlier drafts of the Comment contained detailed analysis questioning whether, under the doctrine of United States $v$. Klein, 80 U.S. (13 Wall.) 128 (1871), Congress was violating the separation of powers by intervening in an ongoing lawsuit. I eventually concluded that it would not.

Klein and a handful of cases in this century discussing it provide the only precedent addressing legislative/judicial, rather than legislative/executive, separation of powers issues. One of the key issucs nnderlying the Klein decision was that Congress tried to use its legislative power over fcdcral courts to achieve indirectly a result that would have been unconstitutional had Congress directly passed legislation arriving at the same result. See, e.g., William A. Fletcher, Atomic Bomb Testing and the Warner Amendment: A Violation of the Separation of Powers, 65 WASH. L. REv. 285, 315-20 (1990) (arguing that the Warner Amendment, which required courts to dismiss pending claims against the government, violated the separation of powers. The amendment was originally a bill Congress had deliberated and declared unconstitutional. Later, it passed as an amendment to another bill without further deliberation.).

As this Section will demonstrate, Congress could pass the Proposed Settlement or any other mass tort judicial reform legislation without independently violating the Constitution. Therefore, under the Klein analysis, Congress would not violate the separation of powers. It would not be using its power over the courts to achieve a result that was unconstitutional for it to legislate. Fully discussing the arguments that ultimately lead to this conclusion, while interesting, proved to digress from the focus of the Comment, and, given my ultimate conclusion about the issue, I chose not to address it in the main text.

149. The Fifth Amendment states that "[n]o person shall ... be deprived of life, libcrty, or property, without due process of law; nor shall private property be taken for public use without just 
Declaring causes of action settled and eliminating existing class action suits suggests a "taking" of property subject to the "just compensation" requirements of the Constitution. The legislative settlement also would have implicated the Due Process Clause because it would have settled cases pending before the courts through retroactive legislation.

Such constitutional challenges, while colorable, would likely have come to naught. Because many of the problems the Proposed Settlement presents resulted from the drafting process rather than from the postenactment impact it might have had on affected people, the judiciary would have been unlikely to find fault with the settlement.

\section{a. Taking Without Just Compensation ${ }^{150}$}

By resolving the claims of individuals, the settlement provisions of the Proposed Settlement would have implicated the "Takings," or "Just Compensation" Clause of the Constitution. Under the Takings Clause, the government may not take property from an individual without paying "just compensation" for the taking. In order to succeed in such a claim, a litigant must establish four elements: (1) the thing that was taken is property as recognized under the Fifth Amendment; (2) the government has "taken" the property; (3) the government has taken the property in the public interest or for a public purpose; and (4) the government has not paid "just compensation" to the individual for the taking. ${ }^{151}$ Because the terms of the Proposed Settlement allowed the government to interfere with private interests by taking away the ability to bring suit and failing to compensate directly affected parties for this loss, it imitially seems to have been the kind of government conduct for which the Takings Clause provides relief.

However, despite the takings implications found in the Proposed Settlement, it is unlikely to have been the kind of government interference that courts would find unconstitutional. Existing precedent comes from a

compensation." U.S. CoNST. amend. V. In addition, claims might arise under the Seventh Amendment (the right to a trial by jury) and the Tenth Amendment along with general federalism concerns. Any claims under the Seventh Amendment would appear to be derivative of the Fifth Amendment claims. The right to a trial by jury could only be violated if the underlying right itself had value. As this Section will demonstrate, existing case law suggests that the causes of action in tobacco tort litigation would not have a value sufficient to justify violations of the Fifth Amendment. Because this Comment argues that Congress is not violating the Constitution by eliminating the underlying right, then there is no additional right to jury trial being taken away. In addition, federalism-based claims are likely, if only because of the interference of federal law with state-created torts. In this situation, lowever, a court would be likely to note that the state attorneys general were primary drafters of this agreement; therefore, it is unlikely that the federal government would be imposing requirements on the states.

150. Contrary to the position of this Comment, one commentator in the National Law Journal suggested that the immunities provisions of the Proposed Settlement would constitute a taking in violation of the Fifth Amendment of the Constitution. See Gideon Kanner, Smoke ' $n$ ' Mirrors in the Tobacco Settlement, NAT'L L.J., Sept. 15, 1997, at A21.

151. See Ruckelshaus v. Monsanto, Co., 467 U.S. 986 (1984) (finding that an EPA requirement exposing a trade secret amounted to a taking without just compensation). 
few lower federal court cases that have explicitly asked whether the government violates the Takings Clause when it settles private claims. These cases have found that such action is constitutionally acceptable. Therefore, the state of the law today suggests that government settlements are not unconstitutional takings.

\section{i. Dames \& Moore v. Regan}

The Supreme Court has not resolved the question whether individuals have valid takings claims against the government when it settles their claims. In 1983, the Court decided Dames \& Moore v. Regan, ${ }^{152}$ a case that challenged the President's authority to suspend legal claims against the Iranian government and to establish the Iran-Umited States Small Claims Tribunal. The President's actions had the effect of eliminating Dames \& Moore's orders of attachment issued by a United States district court. In addition to questioming the scope of the President's power in negotiating the settlement, Dames \& Moore argued that the settlement was a "taking" of its claim against the Iranian government. After upholding the President's power, the Court explicitly left open, in a footnote, the possibility that Dames \& Moore could sue the government to receive "just compensation" for the lost claim: "Though we conclude that the President has settled petitioner's claims against Iran, we do not suggest that the settlement has terminated petitioner's possible taking claim against the United States. We express no views on petitioner's claim that it has suffered a taking." 153 By not resolving the takings question, the Court left the takings issue to the lower federal courts.

\section{ii. Case Law of the Federal Court of Claims}

The Federal Court of Claims has held that a government settlement does not effect an unconstitutional taking. ${ }^{154}$ Although the body of existing case law is small, the court appears to have justified its decisions on two grounds. First, courts are unable to place a monetary value on a cause of action, and therefore cannot provide a remedy for its loss. Second, when

152. 453 U.S. 654 (1981).

153. Id. at 689 n.14.

154. Other federal courts have asked the larger question whether a lost cause of action in tort can amouut to a taking. Most circuits have held it cannot because a cause of action is not property protectable for takings purposes. See, e.g., In re Consolidated Atmospheric Testing Litig., 820 F.2d 982 (9th Cir. 1987), cert. denied, Kozinski v. Livermore Labs, 485 U.S. 905 (1988); Hammond v. United States, 786 F.2d 8 (1st Cir. 1986). The Federal Circuit's reasoning differs from that of the other courts in that it finds a cause of action is protectable property, albeit without a defined value. I have used the Federal Circuit's opinions, rather than those from other circuits, for the following reasons. First, the Federal Circuit's opinions address settlements, making them most applicable to this case. Second, I believe that the Federal Circuit's opinions on this topic are more nuanced than those in other circuits. Regardless of which circuit's logic appears in the text, the holdings in all Circuits have been uniform-no compensation for a lost cause of action. 
the government settles private claims, it may provide the claimants with benefits that justify the taking, and therefore fulfill the "just compensation" requirements of the Constitution.

\section{iii. Valuation Issues and the "Property" Requirement}

The court addressed the valuation issue in Shanghai Power Co. v. United States, ${ }^{155}$ a case in which the Umited States reached a settlement with the People's Republic of China after the Chinese government confiscated all property belonging to U.S. nationals imside China's borders. In Shanghai Power, the plaintiff claimed that the settlement took its property by extinguishing its private right to sue China directly for the value of the confiscated property. ${ }^{156}$ In reaching its decision, the court determined that the lost cause of action was property under the Fifth Amendment, but that the value of the claim was uncertain, and therefore the plaintiff could not claim that the settlement had taken something of value.

To the extent the plaintiff had a legally enforceable right to sue for recovery of its confiscated land, the plaintiff's claim was "property" recognized under the Fifth Amendment. ${ }^{157}$ However, the court concluded that "[t]o hold that plaintiff had property does not, however, establish its value... [because] value would depend upon the likelihood of finding a forum to present the claim, overcoming all relevant defenses and obtaining satisfaction from the debtor's available assets." ${ }^{158}$ In other words, because the value of the property was contingent upon other factors, it lacked any independent value.

The claims that would have been settled by the Proposed Settlement would pose a similar situation for a court. Because they are personal injury claims, a court would have to determine liability, as well as other factors, before it could arrive at a tangible value for the claim. Therefore, under the court's rationale in Shanghai Power, mdividuals with claims settled by the Proposed Settlement would have had a difficult time establishing that a taking had occurred.

\section{iv. The Just Compensation Requirement}

The Court of Appeals for the Federal Circuit grappled with the just compensation requirement of the Takings Clause twice. In Belk $v$. United States, ${ }^{159}$ thirteen Umited States hostages from the Iranian hostage crisis and two of their wives sued the United States for extinguishing their claims against Iran to recover for personal injuries suffered and property taken

\footnotetext{
155. 4 Cl. Ct. 237 (1983).

156. See id.

157. See id. at 240 .

158. Id. at 241 .

159. 858 F.2d 706 (Fed. Cir. 1988).
} 
during the hostage crisis. ${ }^{160}$ In Abrahim-Youri v. United States, ${ }^{161}$ a group of claimants who had prevailed in the Iran-United States Small Claims Tribunal then sued the United States to recover accrued interest on their claims lost when the United States entered into the settlement agreement resolving the claims. The court held for the United States in both actions.

In Belk, the court held that the government was not required to contpensate private individuals for claims lost in a settlement when it brokered the settlement for the benefit of those individuals. The Uinted States entered into the settlement to free the hostages. As a result, the settlement freed the hostages, but barred them from suing Iran for the harms they suffered. Although the United States's actions had cost the hostages their right to sue, the court concluded the government should not be liable to conipensate these hostages in addition to having procured their freedont. As the Federal Circuit stated, "[W] here ... the private party is the particular intended beneficiary of the government activity, 'fairness and justice' do not require that losses which inay result from that activity "be borne by the public as a whole,' even though the activity may also be intended incidentally to benefit the public." ${ }^{162}$ The hostages were free and the settlenient was worth the cost of their lost claims.

The court used similar reasoning in Abrahim-Youri. The Federal Circuit reminded the claimants that, but for government intervention, they would have stood little chance of recovering any noney fron Iran in the foreseeable future. ${ }^{163}$ The court noted that "though the choses in action were extinguished, the Government provided an alteruative tailored to the circunistances which produced a result as favorable to plaintiffs as could reasonably be expected." 164 Similar to the case in 1 Belk, the claimants suing the United States in Abrahim-Youri had been direct beneficiaries of government action taken on their behalf, and therefore could not receive additional conipensation fron the government. ${ }^{165}$ Taken together, these cases suggest that the United States niay settle private causes of action if the settlenient benefits those who lose their claims im soine way.

The Proposed Settlement, while not directly analogous to the Iranian settlement cases, would still be within the class of agreenients to which this logic applies. The United States approached the settlement as a neans of helping the entire population, mcluding injured smokers, against purported

160. See id. at 707.

161. 139 F.3d 1462, 1465 (Fed. Cir. 1997), cert. denied, 118 S. Ct. 2366 (1988).

162. Belk, 858 F.2d at 709 (quoting National Bd. of Young Men's Christian Ass'n v. United States, 395 U.S. 85, 92 (1969)).

163. See Abrahim-Youri, 139 F.3d at 1464 (noting that, prior to the settlement, the Iran-United States Small Claims Tribunal had resolved only eighty-two claims and had yet to hear 2200 others).

164. Id. at 1468 .

165. See id. ("A compensable taking has not been established; the fact that plaintiffs are not satisfied with the settlement negotiated by the Government on their behalf does not entitle them to compensation by the United States."). 
abuses by the tobacco imdustry. Although the agreement would have settled individual claims, other aspects of the agreement would have benefited injured smokers through future programs financed by the settlement. Therefore, when combimed with the valuation problems discussed above, it is unlikely that a court would treat the government's actions in the tobacco settlement as an unconstitutional taking of private property.

\section{Retroactive Application of the Proposed Settlement and the Due Process Clause}

The Proposed Settlement would also have been likely to trigger judicial review under the Fifth Amendment's Due Process Clause, which states the government may not deprive an individual of property without "due process of law,"'166 because it would have operated retroactively, affecting cases pending as of the date of enactment. Still, because the agreement explicitly declared its retroactive intent, a court would have been unlikely to strike it down. Although the Supreme Court has expressed reservations about retroactive legislation, following its policy that "where the congressional intent is clear, it governs," 167 the Court has not struck down an explicitly retroactive statute for decades. ${ }^{168}$ This suggests that any constitutional challenge to the Proposed Settlement on due process grounds would fail.

\section{a. The Court's Case Law on Retroactive Legislation}

Understanding the judiciary's position with regard to retroactive legislation requires an examination of two lines of cases: statutory interpretation cases and constitutional due process cases. The statutory interpretation cases, where the Court has declined to give ambiguous statutes retroactive effect, provide strong policy and historical reasons to support the notion that retroactive legislation violates due process. Nonetheless, on constitutional review, the Court has consistently upheld retroactive laws that explicitly state an intent to have retroactive effect. ${ }^{169}$ This tradition implies that the Court approaches retroactive legislation mindful of the strong policy reasons disfavoring the practice, but finds that such reasons do not satisfy constitutional standards for rejecting retroactive legislation. The Court,

166. U.S. CONST. amend. V.

167. Kaiser Aluminum \& Chem. Corp. v. Bonjorno, 494 U.S. 827, 837-38 (1990).

168. In 1935, the Court invalidated portions of the Railroad Retirement Act of 1934 that required employers to fmance pensions for former railroad employees. See Railroad Retirement Bd. v. Alton R.R. Co., 295 U.S. 330 (1935). Although the Court still formally recognizes Altom as in Usery v. Tumer Elkhorn Mining Co., 428 U.S. 1, 19 (1976), the Court also recognizes that the decision was handed down during the Lochner era, when the Court used "substantive due process" considerations to strike down economic and social regulations. See Pension Benefit Guar. Corp. v. R.A. Gray \& Co., 467 U.S. 717, 733 (1984) (discussing Alton).

169. See, e.g., Landgraf v. USI Film Prods., 511 U.S. 244, 272-73 (1994). 
therefore, will stop short of invalidating retroactively applied statutes if Congress has inade explicit its intent to legislate retroactively.

\section{b. The Presumption Against Giving Retroactive Effect to Ambiguous Statutes}

When asking whether a particular law should be given retroactive effect, the Supreme Court has stated that "retroactivity in the application of new statutes is disfavored."170 The presunption rests initially on a historical practice that predates American law. ${ }^{171}$ Moreover, the principle against retroactivity specifically appears in several places in the Constitution: in the Ex Post Facto Clause, ${ }^{172}$ which prohibits retroactive penal legislation; in the Takings Clause, ${ }^{173}$ which prevents the taking of vested property rights without just compensation; in the Contracts Clause, ${ }^{174}$ which prevents state legislatures from passing laws that interfere with preexisting contractual obligations; and in the prohibition against Bills of Attainder, ${ }^{175}$ which prevents Congress froin singling out people and punishing them summarily for past conduct. ${ }^{176}$

Retroactive legislation poses two dangers: it undermines the citizens' ability to rely on existing laws and it allows the legislature to abuse its lawinaking power. Retroactivity destroys, without notice, existing laws on which citizens have relied. Without notice, people cannot adjust their affairs to take into account changing laws. ${ }^{177}$ Without stable laws upon which to rely, people are deprived of predictability. ${ }^{178}$ Without predictability, society itself is crippled because people cannot go about their normal activities with confidence. Thus, Congress upholds its duty to maintain a stable society by altering the law prospectively.

Retroactive legislation also invites the abuse of legislative power. The Court has worried that the legislature's "responsivity to political pressures

170. See Lindh v. Murphy, 117 S. Ct. 2059, 2061-62 (1997) (rejecting retroactive application of the Antiterrorism and Effective Death Penalty Act of 1996, 28 U.S.C. $\$ 2254$ (d) (Supp. 1997)); see also Landgraf, 511 U.S. at 247 (1994) (rejectiug retroactive application of the Civil Rights Act of 1991, which created a right to recover for compensatory damages under Title VII of the Civil Rights Act of 1964, 42 U.S.C. \$ 1981a(a); Kaiser, 494 U.S. at 840-59 (Scalia, J., concurring) (rejccting construction of the Federal Courts Improvement Act of 1982, amending 28 U.S.C. $\$ 1961$ ).

171. See Kaiser, 494 U.S. at 855 (Scalia, J., concurring) (commenting that the presumption against retroactivity "has timeless and universal human appeal," and was used by the Greeks and Romans, in the English common law, and in the Napoleonic Code).

172. See U.S. ConsT. art. 1, § 10, cl. 1.

173. See id. amend. V.

174. See id. art. $1, \S 10, \mathrm{cl} .1$.

175. See id. art. $1, \$ \S 9-10$.

176. See Landgraf, 511 U.S. at 266.

177. See id. at 265 (Elementary considerations of fairness dictate that individuals should have an opportunity to know what the law is and to conform their conduct accordingly ....").

178. See General Motors Corp. v. Romein, 503 U.S. 181, 191 (1992) ("Retroactive legislation presents problems of unfairness that are more serious than those posed by prospective legislation, because it can deprive citizens of legitimate expectations and upset settled transactions."). 
poses a risk that it may be tempted to use retroactive legislation as a means of retribution against unpopular groups or individuals." 179 Again, the absence of notice forms the crux of the Court's concern. Presumably, if people are given notice of legislative intent to target specific groups or mdividuals, they have the opportunity to use the political process to block such legislation before it is enacted. By providing people with this opportunity, Congress allays fears of retributive treatment. ${ }^{180}$ The presumption against retroactivity, therefore, is a long-standing, well-rooted presumption applied to all statutes where the potential retroactive effect of a statute is im question.

\section{c. The Reasons Statutes That Apply Retroactively Do Not Violate the Due Process Clause}

The policy justifications underlying the presumption against interpreting a law retroactively appear to fall short of constitutional justifications under the Due Process Clause. In recent cases upholding statutes where Congress mcluded language clearly indicating retroactive application, ${ }^{181}$ the Court has made clear that its concerns with retroactivity will not be sufficient to override an otherwise deferential standard of review. ${ }^{182}$ Where retroactive legislation regulates economic and social policy, courts will apply a rational basis test to mquire briefly into the reasons for retroactive application. As the Court explained,

retroactive legislation does have to meet a burden not faced by legislation that has only future effects. "It does not follow ... that what Congress can legislate prospectively it can legislate retrospectively. The retrospective aspects of legislation, as well as the prospective aspects, must meet the test of due process, and the justification for the latter may not suffice for the former." But that

179. Landgraf, 511 U.S. at 266.

180. In any event, a group protected as a "suspect class" would have the protection of heightened scrutiny afforded by the Equal Protection Clause. See U.S. ConsT. amend. XIV.

181. See Usery v. Tumer Elkhom Mining Co., 428 U.S. 1, 16-20 (1970) (upholding challenges to the Federal Coal Mine Health and Safety Act of 1969 as amended by the Black Lung Benefits Act of 1972,30 U.S.C. $\$ 901$ et seq., which set up an administrative scheme to compensate black lung disease victims and their survivors); see also United States v. Sperry Corp., 493 U.S. 52, 64-65 (1989) (upholding constitutionality of $\$ 502$ of the Foreign Relations Authorization Act, note following 50 U.S.C. $\$ 1701$ (1982 ed., Supp. V), which allowed deduction of arbitration fees from judgments issued by the Iran-Umited States Claims Tribunal); Pension Benefit Guar. Corp. v. R.A. Gray \& Co., 467 U.S. 717, 730-34 (1984) (upholding retroactive application of Multieinployer Pension Plan Amendments Act of 1980, 29 U.S.C. $\$ \S 1381,1391$, requiring that an employer withdrawing from a multiemployer pension plan pay a fixed and certain debt to the pension plan).

182. See Lindh v. Murphy, 117 S. Ct. 2059, 2062 (1997) ("When a case implicates a federal statute enacted after the events in suit, the court's first task is to determine whether Congress has expressly prescribed the statute's proper reach. If Congress has done so, of course, there is no need to resort to judicial default rules.") (quoting Landgraf, 511 U.S. at 280). 
burden is met simply by showing that the retroactive application of the legislation is itself justified by a rational legislative purpose. ${ }^{183}$

The Court has identified only two legislative purposes that would cause a retroactive statute to fail: deterrence and blameworthiuess. ${ }^{184} \mathrm{~A}$ retroactively applied statute cannot deter because it sanctions conduct that was acceptable prior to the existence of the statute. Therefore, a retroactive statute aimed at deterring certain conduct cannot rationally achieve its purpose and should be invalidated. The rationale behind blameworthiness is similar. To blame people for conduct that was not blameworthy at the time it was committed would give Congress a retributive power that could be used to hurt unpopular groups or individuals. For all practical purposes, however, Congress may enact a statute that is retroactive on its face.

In explaining its deference to statutes that are explicitly retroactive, the Court has referred to United States $v$. The Schooner Peggy, ${ }^{185}$ an 1801 decision written by Chief Justice John Marshall. The Peggy was a French vessel seized in territorial waters by an American ship and subjected to condemnation proceedings. The circuit court held that condemnation was proper, but before the Supreme Court could issue its decision on appeal, the Umited States entered into an imternational convention with France. ${ }^{186}$ The convention restored to the French all captured property "not yet definitively condemned." 187 The Court interpreted the phrase "not yet definitively condemned"188 as applying to all cases where the property had not yet reached final condemnation, including property taken before enactment of the convention. ${ }^{189}$ Because the convention explicitly required the return of all property that had not been subject to an unreviewable condemnation decision, the Court held that the convention was valid: "[l]f subsequent to the judgment and before the decision of the appellate court, a law imtervenes and positively changes the rule which governs, the law must be obeyed. ..." ${ }^{190}$ Like Chief Justice Marshall, the nrodern Court obeys the express intent of Congress, even when doing so interferes with conipleted acts. ${ }^{191}$

In deferring to the legislature where retroactive inteut is apparent on the face of a statute, however, the Court has not relied purely on stare

183. Pension Benefit Guar. Corp., 467 U.S. at 730 (quoting Turner Elkhorn, 428 U.S. at 16-17) (omission in original).

184. See Turner Elkhom, 428 U.S. at 17-18 ("[W]e would nevertheless hesitate to oppose the retrospective imposition of hability on any theory of deterrence ... or blameworthiness.").

185. 5 U.S. (1 Cranch) 103 (1801).

186. See Kaiser Aluminum \& Chem. Corp. v. Bonjorno, 494 U.S. 827, 845 (1990) (Scalia, J., concurring).

187. The Schooner Peggy, 5 U.S. (1 Cranch) at 107.

188. Id. (emphasis added).

189. See id. at 108.

190. Id. at 110.

191. See Landgraf v. USI Film Prods., 511 U.S. 244, $273-75$ (1994). 
decisis. It appears to believe that including retroactive language in a statute remedies the problein of notice, ${ }^{192}$ which is its concern in the statutory interpretation cases. Without notice problems, groups affected by retroactive application have the opporturity to block a statute in the political process. Therefore, any challenge brought in the courts would simply be the case of a losing party in the political process trying to use the courts as a second chance to achieve its desired outcome. To prevent political losers froin using the courts in this way and to refrain from intervening in political battles, courts refuse to look further than the explicit language of the statute. ${ }^{193}$

In accordance with existing jurisprudence, the Proposed Settlement would have passed rational basis scrutiny. The agreenent clearly stated its retroactive nature. Moreover, the explicit purpose of the settlennent provisions was to effectuate the agreement. In the past, the Court has acknowledged that retroactive application used to effectuate the legislation's goals is constitutionally legitimate. Even though the Proposed Settlement would have stripped soine individuals of their rights by regulating general social policy, it would have passed rational basis review. This loss of individual rights would not violate the Due Process Clause.

\section{IV}

\section{IMPLICATIONS AND RECOMMENDATIONS}

The above analysis shows that the validity of a inass tort settlement such as the Proposed Settleinent would likely depend on which branch of government approved it. A settlement that would fail as a judicial settleinent could succeed as a legislative settlement because courts review legislation differently than they review judicial opinions. So what, if anything, does this difference imply for judicial reform?

\section{A. Implications}

The difference between judicial review of court decisions and judicial review of legislation unay not imply anything. Congress did not approve the settleinent provisions of the Proposed Settlement. Despite the millions of dollars that the tobacco industry spent in lobbying and its explicit promise to prevent Congress from passing any tobacco legislation that lacked settleinent provisions, Congress eliminated the provisions in coinmittee. Just like many other tort reform measures proposed over the last decade, the settleinent provisions never reached the full Senate.

In addition, on the face of the congressional testimony, the Senate went through a highly deliberative process to evaluate the merits of the provisions. In the months that preceded the Commerce Committee's

192. See Pension Benefit Guar. Corp. v. R.A. Gray \& Co., 467 U.S. 717, 732-33 (1984) (discussing the existence of retroactive language in early drafts of legislation).

193. See, e.g., United States R.R. Retirement Bd. v. Fritz, 449 U.S. 166, 179 (1981). 
decision to eliminate the provisions, the Senate invited some of the nation's top legal scholars to analyze whether the provisions were constitutional. ${ }^{194}$ It also heard from both proponents and opponents of the provisions. ${ }^{195}$ Therefore, although individual litigants who would have been affected by the Proposed Settlement were not directly represented during Congress's deliberation on the bill, Congress did take testimony from opponents of the Proposed Settlement whose interests would have overlapped with the interests of imdividual litigants. ${ }^{196}$ Such deliberation evidenced a vigorous political process and, had the Proposed Settlement been enacted, a process that would have taken into account interests of all litigants affected by the agreement. Therefore, despite the fact that post-enactment review of a mass tort reform statute would not take into account issues such as the adequacy of representation for affected litigants, Congress would have already conducted such a review, thus justifying the courts' traditional presumption of deference to the political process. ${ }^{197}$

However, to state that Congress's decisions with regard to the Proposed Settleinent resulted froin a deliberative process would be inaccurate. Political considerations having nothing to do with the merits of the settlement provisions played a significant role in this process. Senator Orrin Hatch admitted as much at the start of hearings three weeks before Senator John McCain eliminated the settleinent provisions from the Proposed Settlement:

[A]doption of limited liability provisions is acceptable if we achieve the substantial public health gains that can be won with this

194. See, e.g., Review of the Global Tobacco Settlement Hearings Before the Senate Judiciary Committee, 105th Cong. (July 1997) (testimony of Laurence H. Tribe, professor of constitutional law, Harvard Law School).

195. See e.g., Hearing on the Proposed Tobacco Settlement Before the Senate Judiciary Committee, 105th Cong. (Mar. 6, 1998) (testimony of Stanley M. Chesley, Esq., on behalf of the Castano Group in stating that the benefits of the settlement justified its concessions); $c f$. Hearing on the Proposed Tobacco Settlement Before the Senate Judiciary Committee, 105th Cong. (Mar. 6, 1998) (testimony of Richard D. Hailey, president, Association of Trial Lawyers of America, arguing against the settlement provisions of the Proposed Settlement) [hereinafter Hailey Testimony].

196. See Hailey Testimony, supra note 195 (stating that "trial lawyers have been instrumental in fighting against big tobacco on behalf of so many Americans who have been hurt, disabled, and killed by tobacco products").

197. See, for example, how this description of the hearings on the Proposed Settlement mirrors Chief Justice Marshall's account in McCulloch v. Maryland, 17 U.S. (4 Wheat.) 316 (1819), of the passage of the bill that incorporated the Bank of the United States:

The bill ... did not steal upon an unsuspecting legislature and pass unobserved. Its principle was completely understood, and was opposed with equal zeal and ability. After being resisted, first in the fair and open field of debate, and afterwards in the executive cabinet, with as much persevering talent as any measure has ever experienced, and being supported by arguments which convinced minds as pure and intelligent as this country can boast, it became a law.... It would require no ordinary share of intrepidity to assert that a measure adopted under these circumstances was a bold and plain usurpation, to which the constitution gave no countenance.

Id. at 402 . 
settlement. . . . Many have criticized this "quid pro quo" argument, saying it is possible to write a strong bill without the industry's assent. Let me be clear. We do not need the agreement of the tobacco industry to pass this legislation. But, as a Senator who devoted the majority of last year with my colleague from Massachusetts and others for a 43-cent tobacco tax increase, and who wound up with considerably less, let me tell you. ... The tobacco mdustry has shown it will not lie down. In my view, absent liability provisions ... we will be unable to change materially the way im which these products are advertised and marketed. ${ }^{198}$

Senator Hatch's observations about Congress's ability to legislate meaningfully over the industry without the settlement provisions proved true. Once the Commerce Committee decided to eliminate the settlement provisions, the tobacco mdustry successfully used its lobbymg machine to block the legislation. ${ }^{199}$ Tobacco politics undoubtedly had an impact on the deliberative process.

The politics surrounding the Proposed Settlement appear to support theories drawn from the academic literature about the impact special imterest groups can have on the political process. The political process is a complex arena in which interest groups seek to influence the political system. ${ }^{200}$ Special interests compete against other factors, like ideology and altruism, that also influence legislative outcomes, ${ }^{201}$ and sometimes seek compromise with competing interests to achieve desired results. ${ }^{202}$ The extent to which interest group pressure influences legislative decision making is not constant; some legislation is more the result of special interest pressure than is other legislation. ${ }^{203}$ No particular outcome is ever guaranteed, but interest groups succeed in getting legislation passed over time. ${ }^{204}$

The description of an unpredictable, yet politically influenced, legislative process would appear to account for what happened to the Proposed Settlement in the Senate. Tobacco pushed its political agenda in Congress. Congress's desire to follow this agenda was tempered by competing

198. Hearings on the Proposed Settlement Before the Senate Judiciary Committee, 105th Cong. (1998) (statement of Orrin Hatch, Chair, Senate Judiciary Committee) [hereinafter Hatch Testimony].

199. Senator McCain said after the Senate retumed his bill to committee, "I think you have to give the tobacco coinpanies credit. They won." Jim Drinkard, Who Killed It? Backers Blame Politics; Opponents Point to Pork, USA ToDAY, June 18, 1998, at A1.

200. See Einer R. Elhauge, Does Interest Group Theory Justify More Intrusive Judicial Review?, 101 YALE L.J. 31, 35-44 (1991) (reviewing the literature on interest group influence).

201. See Daniel A. Farber \& Philip P. Frickey, The Jurisprudence of Public Choice, 65 TEx. L. REV. 873, 912-14 (1987).

202. See generally Eric A. Posner, The Political Economy of the Bankruptcy Reform Act of 1978, 96 MrCH. L. REV. 47 (1997) (suggesting coalition building and compromise between interests explains provisions in the Bankruptcy Act).

203. See Cass R. Sunstein, Naked Preferences aud the Constitution, 84 Colum. L. REv. 1689, 1695 (1984).

204. See generally Daniel A. Farber \& Philip P. Frickey, LaW and Public Cholce (1991). 
considerations. The high visibility of congressional deliberations on the bill, the demands of the pubhic health commumity for stringent regulation, ${ }^{205}$ the continuing revelations about the tobacco companies' targeting of minors, and the deliberative process itself all likely played roles in the final outcome to remove the settleinent provisions. In addition, the blatant exchange that the tobacco industry offered as the only way to pass legislation-regulation for settlement provisions-loomed. At some point, Senator McCain and his Senate drafters gambled against the risk that the tobacco companies would be able to kill legislation lacking the settlement provisions. They lost this ganible. ${ }^{206}$ All of these factors serve to suggest that politics had a strong role in determining the fate of the Proposed Settlement.

If political considerations played a significant, possibly defining role in the discussions over the Proposed Settlement, then the observations raised in Part III, supra, have significant implications for mass tort reform legislation. Had the political climate been a little different, Congress could have retained the settlement provisions and the resulting legislation might have passed. ${ }^{207}$ Rather than a inodel of a vigorous deliberative process, the political overtones of the Proposed Settleinent suggest a Congress willing to pass legislation as a means of advancing a desired outcome, even when that legislation mcludes major concessions to outside interests.

This is not to say that political compromise is necessarily a negative factor in legislation, or even to suggest a goal like health care reform is not worth significant compromise if the resulting legislation benefits the public. ${ }^{208}$ This Comment, however, only addresses the implications that legislation liolds for mass tort reform. From that perspective, problens arise from the possibility that Congress might modify the judicial structure through politically motivated legislation in ways that dictate the results of ongoing litigation and affect future patterns of litigation. The legislature could end up passing legislation that benefits special interest groups while failing, like the judiciary, to protect individual litigants from the effects of collusion.

As this Comment has discussed, critiques of class action settlements focus on the potential for collusive results that benefit defendants and class

205. See, e.g., Hearings on the Tobacco Settlement Before the Senate Commerce, Science, and Transportation Committee, 105th Cong. (1997) (Joint Statement of Drs. C. Everett Koop \& David A. Kessler, Co-Chairs, Advisory Committee on Tobacco Policy and Public Health).

206. Of course, this too is likely a simphistic spin on a much more complicated process. The bill ended up having riders and amendments attached, greatly mcreasing its size and also the likelihood that it would intrude on constituent interests. See David E. Rosenbaum, supra note 61 at A1 (describing low the bill grew). Despite these other considerations, the tobacco lobby played a key role in the legislation's defeat.

207. Hatcl Testimony, supra note 198 (noting that the Clinton Adiministration would accept all of the provisions if they passed a Senate vote).

208. A discussion of either of these topics is beyond the scope of this Comment. 
counsel at the expense of claimants. These results are perceived as problems because one goal of the judicial process is to minimize power differences between litigants. Over time, a body of precedent has arisen that tries to guarantee access to a neutral forum for all litigants. ${ }^{209}$ Thus, when the courts approve settlements that reflect collusion, the judicial system has failed to realize its institutional guarantees. Despite this failure, the Windsor decision shows that the judiciary condemns collusive practices and will struggle against them to provide the levels of representation and due process that the institution promises.

The legislature is a very different institution from the judiciary. Unlike the judiciary, the legislature does not have any defined requirements of due process or adequacy of representation. Actions that might be characterized as collusive by the judiciary, such as the vast lobbying expenditures that the tobacco companies paid to support their legislation and the political exchange between public health and litigation relief they offered to Congress as a condition of their support of any tobacco legislation, are accepted as part of the political process. More-over, mass tort reform legislation is capable of affecting all litigants, present and future, at once; therefore, the damaging potential of biased legislative reform is much more extensive than that of a collusive judicial settlement, which affects individuals only on a case-by-case basis.

In addition, as Part III revealed, legislation would likely be insulated froin challenge. The affected parties face an enacted statute subject only to substantive review. Under that standard, opponents of the legislation would be unlikely to undo the result in court. While they could lobby the legislature to modify or repeal the statute, such efforts would not be likely to succeed.

The damaging potential of legislative reform is not limited to the individuals it would affect. The possibility of politically inotivated inass tort legislation presents problems for the judiciary as an institution. The most likely proponents of such legislation are the same special interests who are the defendants in these inass tort suits. Unconstrained in the political process, special interests like the tobacco industry could use the legislature to achieve permanent results they might not be able to achieve in the judicial process. If a special interest like the tobacco industry has the potential to influence legislation modifying the courts' adjudicative process at the same

209. See Vitek v. Jones, 445 U.S. 480 (1980); Arnett v. Kennedy, 416 U.S. 134 (1974) (regarding the right to an impartial decisionmaker); NAACP v. Button, 371 U.S. 415 (1963) (upholding the right to provide free legal services); McVeigh v. United States, 78 U.S. (1 Wall.) 259 (1870) (regarding the right to be heard); Owen M. Fiss, Against Settlement, 93 YALE L.J. 1073, 1076 (1984) (observing that disparities between parties "will invariably infect the bargaining process, and the settlement will be at odds with a conception of justice that seeks to make the wealth of the parties irrelevant"); $c f$. Lassiter v. Dep't of Soc. Serv., 452 U.S. 18 (1981) (regarding the diminished right to counsel in civil cases). 
time it is a defendant in ongoing litigation, then the legislation not only circumvents the judicial process, but also potentially rewrites the rules governing the judiciary in ways that conflict with its institutional goal of acting as a neutral forum. Given the uncertainties of the political process, Congress may not pass mass tort reform. However, since reform, if enacted, would be difficult to challenge successfully in post-enactment review, ways to prevent special interest legislation from passing need to be analyzed.

\section{B. Recommendations}

Mass tort legislation presents the proverbial double-edged sword. On the one hand, because limits exist on the judicial power to provide remedies to mass tort litigation, reforn, if needed, must come from Congress. On the other hand, should Congress pass institutional reform tainted by special interest group imterference, it could exacerbate the very problems of collusion and insufficient protection of individuals that have concerned several commentators in the context of class action settlements. Moreover, given that different priorities govern judicial review over judicial and legislative settlements, post-enactment modification is unlikely in the courts. The challenge, therefore, is to prevent political maneuvering from displacing the deliberative process when Congress considers enacting mass tort reform legislation that modifies the adjudicative process.

At least two possible ways of addressing this possibility exist. ${ }^{210}$ First, the courts could alter judicial review as it pertains to legislative settlements. Second, Congress could take steps internally to mitigate possible negative effects of special interest group influence over the legislative process. ${ }^{211}$ This Comment does not examine the first possibility. Addressing the disparity between judicial review of legislative settlements and judicial review of judicial settlements would require the courts to change the way they evaluate constitutional provisions such as the Due Process Clause of the Fifth Amendment. Because the federal courts have moved increasingly away from the use of intrusive judicial review, ${ }^{212}$ they are not

210. In addition, affected individuals could always lobby for repeal after legislation passed. However, this last solution seems the least likely of all. If the problem is pervasive special interest group influence in the legislature, then defendants like the tobacco industry would be able to block repeal attempts.

211. Congress would need to take steps regulating its own conduct because attempts to restrict contributions and lobbying would run into First Amendment concerns. See, e.g., Buckley v. Valeo, 424 U.S. 1 (1976) (holding that campaign finance law restrieting contributions violated First Amendment free speech protections).

212. See generally Erwin Chemerinsky, The Supreme Court, 1988 Term-Foreword: The Vanishing Constitution, 103 HARv. L. REv. 43 (1989) (critieizing the Rehnquist Court and much of the trend in the twentieth century against conducting a substantive review of federal statutes). 
a viable forum to resolve the issues presented by the Proposed Settlement. ${ }^{213}$

A legislative solution, while somewhat unsatisfactory, appears to be the default choice. Seeking to resolve the problems of interest group influence from the very body that benefits from such influence presents its own practical difficulties. Nevertheless, because Congress has a constitutional mandate to pass judicial reform legislation, ${ }^{214}$ and the courts are unlikely to provide any alternative solution, this Comment articulates a pair of basic guidelines that principled legislators could follow to mitigate special interest group influence over mass tort reform legislation. ${ }^{215}$

First, Congress needs to understand that the judicial system and the legislative system protect different interests. Although the power to implement reform lies with Congress, regulating the judiciary could affect the courts' role as relatively neutral forums available to provide remedies for all litigants. Principled legislators should first ask how the judiciary currently addresses mass tort litigation and what implications legislative reform will have on the judiciary's institutional values.

Second, recognizing judicial values, Congress should establish requirements to minimize the influence that special interests have on committee members evaluating and drafting judicial reform legislation. Although it may not be possible to find entirely unbiased conımittee members, rules and regulations could prohibit committee members from drafting judicial reform legislation if they receive substantial contributions from special interest groups with a direct stake in the outcome of ongoing litigation. This may mitigate some of the direct influence that special interests assert over the legislative process. Bribing judges is proscribed. The same should be true of legislators who inake law that will determine judicial outcomes.

From these basic principles, Congress could, if it chose, draft legislation that would affect the judiciary without additionally allowing special interest groups to use their influence in the political process to affect

213. Entertaining the concept of increased judicial review would also wade into an ongoing debate on the topic that extends beyond the scope of this Comment. While some scholars have advocated such change, see id., especially increasing the level of scrutiny given to legislation influenced by special interest groups, see Jerry L. Mashaw, Constitutional Deregulation: Notes Toward a Public, Public Law, 54 TuL. L. REv. 849, 849-51 (1980), others argue that the Constitution does not explicitly grant the courts power to evaluate "the due process of lawmaking," see generally Hans A. Linde, The Due Process of Lawmaking, 55 NEB. L. REv. 195 (1976). Regardless, because courts would not adopt increased judicial review in practice, this Comment does not engage this debate.

214. This comes both from the power granted in Article III to create lower federal courts and to legislate "exceptions" and "regulations" over the Supreme Court's jurisdiction and a body of case law recognizing Congress's right to make substantive law and dictate the procedures that courts use to adjudicate that law. See, e.g., U.S. CoNST. art. III, § 2, cl. 2; Dice v. Akron, 342 U.S. 359 (1952).

215. These guidelines are my suggestions to the "conscientious legislator." See generally Paul Brest, The Conscientious Legislator's Guide to Constitutional Interpretation, 27 STAN. L. REV. 585 (1975). 
outcomes. If legislation like the Proposed Settlement resulted from the deliberative process that congressional testimony reveals, and not from special imterest group influence over the political process, the conclusions reached im Part III, supra, would not raise concern. Congress would have provided guarantees that it was vigorously scrutinizing legislation in ways that justify the judiciary's traditional deference to the political process.

\section{CONCLUSION}

The Proposed Settlement was the first post-Windsor opportunity for Congress to legislate mass tort litigation relief. Legislative settlements are likely necessary to resolve mass tort litigation. The judiciary is limited in the range of solutions that it can provide by both the Constitution and statute. In addition, although courts are suitable forums for resolving tort claims generally, the complexities of these suits, with their divergent claims, cause conflicts between present and future interests. Furthermore, the possibility of wildly mconsistent judgments issued by different courts for similar mjuries, combimed with the desire to spend a limited financial pool to accommodate all injured parties, ${ }^{216}$ suggest the need for a forum designed to address polycentric disputes. That forum is the legislature.

Seeking legislative solutions for mass tort claims potentially allows special imterest groups to affect the political process, thus indirectly influencimg judicial results in ways beneficial to those interests. The Supreme Court sent out an imvitation in Windsor for Congress to become involved in mass tort reform. This Comment seeks to qualify to that invitation. In order for Congress to play the role suggested to it by the Supreme Court in Windsor, it should take care to assure that judicial reform legislation results from a deliberative process rather than one influenced by special interests. Only then can Congress wield its powers of reform in ways that will do justice to the judicial structure itself.

216. See, e.g., The Tobacco Settlement: Views of the Administration and the State Attorneys General Before the House Committee on Commerce, 105th Cong. (1997) (testimony of Gale A. Norton, attorney general of the State of Colorado). 